\title{
Treatment for Viral Hepatitis as Secondary Prevention for Hepatocellular Carcinoma
}

\author{
Saleh A. Alqahtani ${ }^{1,2, * \mathbb{D}}$ and Massimo Colombo ${ }^{3}$ \\ 1 Division of Gastroenterology and Hepatology, Johns Hopkins University, Baltimore, MD 21287, USA \\ 2 Liver Transplant Center, and Biostatistics, Epidemiology, and Scientific Computing Department, King Faisal \\ Specialist Hospital \& Research Center, Riyadh 11564, Saudi Arabia \\ 3 Liver Center, IRCCS San Raffaele Hospital, 20132 Milan, Italy; mcolombo46@yahoo.it \\ * Correspondence: salqaht1@jhmi.edu
}

check for

updates

Citation: Alqahtani, S.A.;

Colombo, M. Treatment for Viral Hepatitis as Secondary Prevention for Hepatocellular Carcinoma. Cells 2021, 10, 3091. https://doi.org/10.3390/ cells10113091

Academic Editor: Marc Basson

Received: 14 September 2021

Accepted: 7 November 2021

Published: 9 November 2021

Publisher's Note: MDPI stays neutral with regard to jurisdictional claims in published maps and institutional affiliations.

Copyright: (c) 2021 by the authors. Licensee MDPI, Basel, Switzerland. This article is an open access article distributed under the terms and conditions of the Creative Commons Attribution (CC BY) license (https:// creativecommons.org/licenses/by/ $4.0 /)$.

\begin{abstract}
Chronic infections with either hepatitis B or C virus (HBV or HCV) are among the most common risk factors for developing hepatocellular carcinoma (HCC). The hepatocarcinogenic potential of these viruses is mediated through a wide range of mechanisms, including the induction of chronic inflammation and oxidative stress and the deregulation of cellular pathways by viral proteins. Over the last decade, effective anti-viral agents have made sustained viral suppression or cure a feasible treatment objective for most chronic $\mathrm{HBV} / \mathrm{HCV}$ patients. Given the tumorigenic potential of $\mathrm{HBV} / \mathrm{HCV}$, it is no surprise that obtaining sustained viral suppression or eradication proves to be effective in preventing HCC. This review summarizes the mechanisms by which HCV and HBV exert their hepatocarcinogenic activity and describes in detail the efficacy of anti-HBV and anti-HCV therapies in terms of HCC prevention. Although these treatments significantly reduce the risk for HCC in patients with chronic viral hepatitis, this risk is not eliminated. Therefore, we evaluate potential strategies to improve these outcomes further and address some of the remaining controversies.
\end{abstract}

Keywords: HCC; HBC; HCV; hepatocellular carcinoma; prevention

\section{Introduction}

Primary liver cancer ranks as the sixth most common cancer globally and the third leading cause of cancer-related death [1]. Hepatocellular carcinoma (HCC) is by far the most dominant histological subtype of liver cancer, accounting for about four-fifths of all cases [2]. Globally, the incidence of HCC is increasing, with GLOBOCAN predicting an increase from 841,000 cases in 2018 to 1.4 million cases in 2040. In parallel, it also predicts increased mortality, from 780,000 deaths in 2018 to 1.3 million in 2040 [3]. Infections with hepatitis $\mathrm{B}(\mathrm{HBV})$ or $\mathrm{C}$ virus $(\mathrm{HCV})$ represent the most significant risk factors for the development of HCC, followed by heavy alcohol consumption. Epidemiological data from 50 countries indicate that at least $60 \%$ of all HCC cases are attributable to either $\mathrm{HBV}$ or HCV [4]. Although virus-related HCC is prevalent worldwide, there are notable geographical variations in the proportion of patients with HCC associated with HCV versus those with $\mathrm{HBV}$. Reflecting the incidence and distribution of these two hepatitis viruses, $\mathrm{HBV}$-induced $\mathrm{HCC}$ is more common in countries with a low to middle human development index. In contrast, HCV is responsible for most virus-related HCC cases in regions with a higher developmental index [5].

\section{HBV}

HBV is a small, partially double-stranded DNA virus belonging to the hepadnaviridae family. In 2015, 257 million persons, $3.5 \%$ of the global population, were living with a chronic HBV infection, making it the most common blood-borne infection in the world [6]. Patients with chronic hepatitis $\mathrm{B}(\mathrm{CHB})$ may develop cirrhosis, and the 5-year cumulative incidence ranges between $8 \%$ and $20 \%$. About $2 \%$ to $5 \%$ of patients who develop cirrhosis 
may then face an HCC risk annually [7]. During early 1980s, a hepatitis B vaccine was developed, successfully reducing the disease burden. By 2015, the global coverage of persons with three doses of this $\mathrm{HBV}$ vaccine was $84 \%$. Consequently, the global proportion of HBV-infected children younger than five years old dropped from $4.7 \%$ in the prevaccination era to $1.3 \%$ in 2015 [8]. Evidence continues to accumulate, showing that this mass vaccination substantially reduces the disease burden associated with HBV. For example, mass vaccination campaigns in China reduced the prevalence of new HBV infections by $90 \%$. Models estimate that this prevented around 2.8 million to 3.5 million deaths associated with HBV in the future. Most were predicted to be associated with HCC [9]. For chronic HBV carriers, the current therapeutic options do not provide a virological cure, but treatments with nucleos(t)ide analogs (NAs) can effectively reduce the risk of HCC $[10,11]$.

\section{3. $\mathrm{HCV}$}

$\mathrm{HCV}$ is a single-stranded RNA virus belonging to the Flaviviridae family. Every year, approximately 1.75 million persons are infected with $\mathrm{HCV}$, and HCV-related liver cirrhosis or HCC results in the death of over 350,000 patients. In 2020, 58 million people were estimated to have chronic $\mathrm{HCV}$ infection [8]. In patients with a chronic HCV infection, the risk of HCC gradually increases with the progression of liver fibrosis. Once cirrhosis is established, the annual incidence of HCC is high at 2 to $8 \%$ per year [12]. In contrast to $\mathrm{HBV}$, there is currently no preventive vaccine for HCV. However, over the last decade, very effective direct-acting anti-viral agents (DAAs) have been developed that can cure the vast majority $(>90 \%)$ of HCV patients. Studies with these agents have convincingly demonstrated that obtaining a sustained virological response (SVR) with DAAs significantly reduces the risk of HCC [13].

To underscore the importance of viral clearance in the prevention of HBV- or HCVrelated HCC, this review provides firstly a brief overview of the molecular mechanisms that form the basis of the oncogenic potential of these viruses. Subsequently, we provide evidence supporting the efficacy of the current HBV and HCV treatment strategies in averting the development of HCC. With these treatment modalities, the risk for HCC in patients with chronic viral hepatitis is significantly reduced but not abolished. Therefore, we address potential strategies to improve these outcomes further and discuss some of the remaining controversies.

\section{Molecular Mechanisms by Which HBV and HCV Induce HCC}

Chronic infections with HBV or HCV significantly increase the risk of developing HCC $[7,14,15]$. However, not all persistently infected individuals develop liver cancer, indicating that chronic infection with these viruses by themselves is generally not enough to develop cancer. As with many cancers, multiple factors contribute to oncogenesis. HBV and HCV only provide a portion of the oncogenic pressure (Figure 1) and combine with other factors (such as environmental, lifestyle, or genetic factors) to develop HCC [16]. 

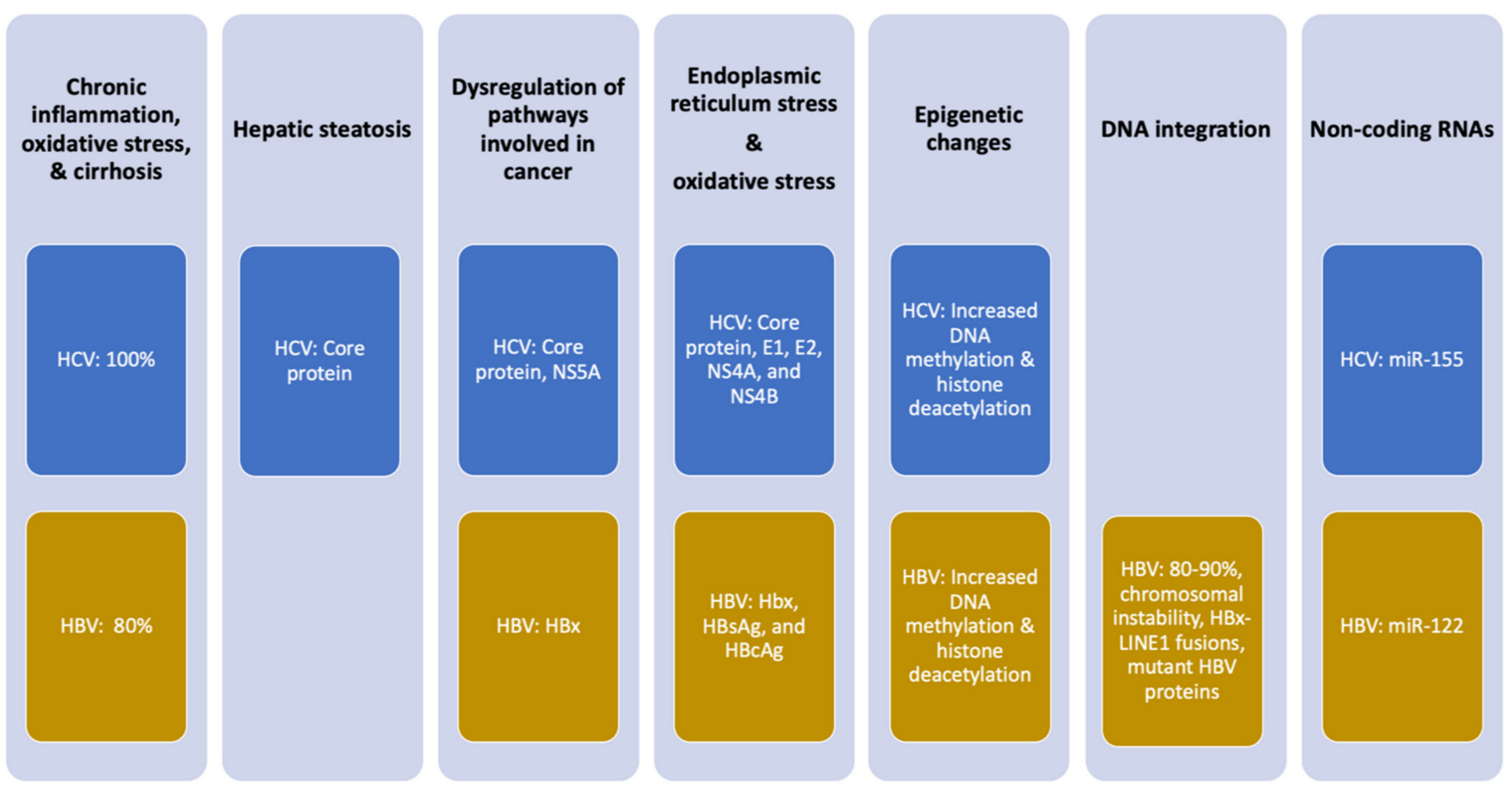

Figure 1. Mechanisms of oncogenesis by HCV and HBV. Percentages indicate the frequency with which the effect is observed in patients with infection-associated HCC. Viral proteins implicated in the oncogenic mechanism are noted.

\section{Chronic Inflammation}

A crucial mechanism by which chronic HCV and HBV drive the development of HCC involves chronic liver inflammation. HCV-related HCC often develops exclusively in the context of liver cirrhosis [17]. Although most HCC cases develop in patients with chronic HBV infection and cirrhosis, there are still $10-20 \%$ of HBV-related HCC cases that occur in the absence of cirrhosis [18]. The persistence of inflammatory stimuli resulting from a chronic HCV or HBV infection combined with dysregulated immune regulatory mechanisms causes a state of constant inflammation, leading to fibrosis, cirrhosis, and neoplastic transformation in the liver parenchyma. This immune-mediated liver damage is mainly caused by the release of reactive oxygen species (ROS) and pro-inflammatory cytokines by hepatocytes and immune cells (in particular, natural killer cells and T cells). The resulting necroinflammation stimulates hepatocyte regeneration and wound healing. When a patient fails to clear HBV or HCV completely, this constant process of necroinflammation and subsequent wound healing responses gradually increases the oxidative stress in the liver, leading to the induction of epigenetic and oncogenic alterations, telomere shortening, and genomic instability [19]. Specifically for HCV, researchers have found that the incomplete eradication of $\mathrm{HCV}$ results in the selection of escape mutants that evade the immune system and establish a chronic infection [20]. In addition to fueling the persistent inflammatory state, the release of ROS and specific cytokines results in the activation of stellate cells and fibroblasts in the liver. In turn, these cells enhance the synthesis of collagen and alter the extracellular matrix, ultimately leading to fibrotic remodeling of the liver microenvironment [21].

\section{Viral Proteins Deregulate Cellular Pathways and Induce Oxidative Stress}

In addition to the inflammation-mediated, indirect oncogenic effect, both HCV and $\mathrm{HBV}$ also directly influence hepatocarcinogenesis. This direct oncogenic effect involves specific viral proteins.

The HBV protein HBx exhibits carcinogenic activity. HBx modulates several inflammation pathways such as signal transduction and, consequently, the progression of liver disease, including the MAPK, NF-KB, IL-6/STAT3, and PI3K pathways, as well as signaling 
by Src [22]. HBx also activates the Wnt/ $\beta$-catenin pathway, leading to an accumulation of $\beta$-catenin and the subsequent induction of pro-angiogenic factors [23]. Interestingly, HBx binds to the tumor suppressor p53 in the cytoplasm, preventing the translocation of p53 into the nucleus, where p53 is involved in responding to DNA damage by activating cell cycle checkpoints, apoptosis, and DNA repair [24]. Ultimately, this hampered p53 activity leads to genomic instability, which drives neoplastic transformation. A second mechanism by which HBx promotes the development of HCC consists of epigenetic regulation. HBx encourages the expression of several DNA methyltransferases, which in turn regulate the face of a broad range of proto-oncogenes and tumor suppressors via hypoand hypermethylation. $\mathrm{HBx}$ also exhibits epigenetic activity through the promotion of histone (de)acetylation of cancer-related genes, microRNAs (e.g., miR-122), and non-coding RNAs [25].

In HCV-infected hepatocytes, the HCV core protein and NS5A are essential for altering signaling through pathways involved in cancer [26]. The HCV core protein impacts cell growth, differentiation, apoptosis, transcription, and angiogenesis. Its mechanism of action is to activate MAPK, Wnt/ $\beta$-catenin, TGF- $\beta$, PI3K/Akt/mTOR, NF-kB, IL-6/STAT3, and androgen receptor signaling and suppress apoptotic signaling. Similarly, NS5A engages with several pro-oncogenic pathways, such as $\beta$-catenin, PI3K/AKT/MTOR, NF- $\mathrm{kB}$, and p53 [27].

Both viruses influence chromatin structure and gene expression by altering epigenetic regulation and the production of microRNAs. Through these mechanisms, viral proteins from each virus also impact pathways implicated in oncogenesis and contribute to HCC development. HBx of HBV and HCV core protein alter epigenetic events by increasing DNA methyltransferase activity and histone deacetylation [28,29]. HBx also increases miR-122 and other non-coding RNAs [25]. HCV core protein increases miR-155, which is markedly increased in patients infected with $\mathrm{HCV}$ and stimulates hepatocyte proliferation and tumorigenesis by activating Wnt signaling [30,31].

Both HBV and HCV replication involves the endoplasmic reticulum, the site where viral proteins are produced, and the source of the lipids surrounding the virus. Along with $\mathrm{HBx}$, the HBV proteins $\mathrm{HBsAg}$ and $\mathrm{HBcAg}$ are associated with the induction of oxidative stress as a result of impaired protein folding in the endoplasmic reticulum. The HCV core, E1, E2, NS4A, and NS4B proteins also cause this endoplasmic reticulum stress [19]. During infection, the production of these viral proteins leads to the accumulation of misfolded proteins in the endoplasmic reticulum, which activates the unfolded protein response. As part of this response, calcium ions are released from the endoplasmic reticulum into the cytoplasm, which stimulates ROS production that can induce inflammation, tissue damage, and fibrosis and contribute to the development of HCC [19].

\section{HCV-Induced Hepatic Steatosis}

A specific oncogenic effect of $\mathrm{HCV}$ relates to hepatic steatosis, which is defined as an excessive triglyceride presence in hepatocytes. Hepatic steatosis is independently associated with HCC development in patients with HCV-related cirrhosis [32]. HCV core protein alters lipid metabolism. In a transgenic mouse model, overexpression of $\mathrm{HCV}$ core protein reduces triglyceride transfer protein activity, which results in the accumulation of triglycerides in hepatocytes and causes oxidative stress that contributes to an oncogenic liver environment [33].

\section{HBV Integration in Host DNA}

A carcinogenic mechanism specific to $\mathrm{HBV}$ is the genomic integration of HBV DNA into the hepatocyte genome, a feature that is observed in $80-90 \%$ of HBV-related HCC cases [34]. HBV DNA integration appears to occur early in the infection. Viral DNA integration fuels hepatocarcinogenesis through three mechanisms. First, HBV DNA integration causes genomic instability, a known hallmark of cancer. Although integration occurs in most infected individuals, those without HCC have HBV sequences randomly 
integrated throughout the genome. In contrast, HBV DNA integration in patients with HCC is enriched in regions known to cause chromosomal instability [35]. Secondly, more comprehensive sequencing studies show recurrent HBV DNA integration sites at genetic loci that encode for proteins with significant involvement in initiating HCC carcinogenesis [34]. A prime example is HBx-LINE1 gene fusions, a genomic aberration that can be found in about a quarter of HBV-associated HCCs [36]. Finally, the integration of HBV DNA can also lead to the production of mutant HBV proteins, leading to an overload of the endoplasmic reticulum, resulting in oxidative stress [37].

\section{Predictors of HCC and Screening Strategies}

The neoplastic transformation of chronic hepatitis B is driven by an interplay between direct and indirect mechanisms of carcinogenesis in the context of chronic inflammation and the regeneration of liver cells [26]. Understanding factors that at the individual level promote liver carcinogenesis is of paramount importance for the configuration of costeffective screening programs and linkage to patient care. Not surprisingly, several viral covariates have been associated with HBV transition to HCC, the most robust predictor of HCC being a high viral load, independent of the patient's cirrhosis status or high HBsAg levels [38-40]. Thus, this finding sets the stage for anti-viral therapy to become the only realistic approach to temper the risk of the neoplastic transformation of chronic HBV infection progression.

The follow-up reanalysis of 48,149 patient years from the REVEAL study in Taiwan offered essential insights into the association between the lifetime risk of HCC and the $\mathrm{HBV}$ infection phase. HCC risk was strikingly high in males and HBeAg seroconverters who had remained HBV DNA-seropositive compared to those who cleared both HBsAg and HBV DNA (80.1\% vs. 4.0\%) [41]. However, HBsAg seroclearance occurs in less than $10 \%$ of patients treated with NAs and interferon (IFN) and is associated with HBV DNA detectability in the liver $[42,43]$. The HCC risk is higher in older HBV patients, implying the pathogenic relevance of the infection length and the age-dependent loss of protective mechanisms against cancer. In a multiethnic milieu such as the US, the HCC risk was higher in HBV carriers of African American origin than in Whites, Latinos, and Asians [44]. Together with genetic studies, these findings highlighted the importance of genetics as an outcome modifier of HBV infection and opened the way to studies of single-nucleotide polymorphisms that have been identified to confer susceptibility to HCC. In contrast, evidence started to accumulate that an interaction between a genetic predisposition to HCC and the lifestyle choices of HBV carriers have a severe impact on the risk of HCC development. One study demonstrated the lethal consequences of alcohol abuse that have long been recognized in both hemispheres, since drinking alcohol accelerates the development and progression of liver cirrhosis and HCC in HBV patients in a dose-response pattern, and some studies also exhibit a positive interaction with tobacco smoking [45]. In the seminal studies performed decades ago, tobacco was found to boost the risk of HCC development in HBV patients independently of other confounders, including alcohol. This association was later confirmed by a large meta-analysis, in which the hazard (random effect) of HCC development was 1.87, 15.8, and 21.6 for HBV-seronegative smokers, HBV-seropositive non-smokers, and HBV-seropositive smokers, respectively [46]. In HBV-infected patients, steatosis is related to an increased risk of liver fibrosis, followed by HCC progression, independently of anti-viral therapy $[47,48]$. In a meta-analysis including almost 22,000 patients, the presence of diabetes, a dominant culprit in liver steatosis, was associated with significantly increased overall mortality (pooled RR: 1.93 (1.64-2.27)) compared to HBV carriers without diabetes [49].

\section{Prediction Models and Scoring Systems for HCC Development}

Ultimately, the essential variables concerning the HCC risk in hepatitis B carriers are linked to the liver disease stage and hepatic fibrosis. The stage of liver fibrosis can be assessed with non-invasive methods that have been validated in patients with other 
chronic liver diseases. The most popular method includes transient elastography, which measures liver stiffness. Scores based on a combination of serum markers [50-52], which incorporate host, viral, and liver disease variables, accurately predict the HCC risk in patients with a chronic HBV infection. (Table 1) [40,47,53-55]. Following the selection of an appropriate cut-off value, all these scores for HCC exhibit a substantial negative predictive value in the range of 5 to 10 years. The European Association for the Study of the Liver (EASL) endorses the PAGE-B score for HCC risk stratification, recommending biannual screening with abdominal ultrasound for HBV carriers with a score of 10 or more [56]. Full descriptions of each scoring system are beyond the scope of this review but are summarized in Table 1.

Table 1. Models that could predict HCC development in patients with HBV.

\begin{tabular}{|c|c|c|c|c|c|c|}
\hline & $\begin{array}{c}\text { Chinese University } \\
\text { Model [40] }\end{array}$ & $\begin{array}{c}\text { Guide with Age, } \\
\text { Gender, HBV DNA, } \\
\text { Core Promoter } \\
\text { Mutations, and } \\
\text { Cirrhosis (GAG } \\
\text { Model) [53] }\end{array}$ & $\begin{array}{c}\text { Risk Estimation for } \\
\text { HCC in CHB } \\
\text { (REACH-B Model) } \\
\text { [54] }\end{array}$ & $\begin{array}{c}\text { Modified } \\
\text { REACH-B Model } \\
{[57]}\end{array}$ & $\begin{array}{l}\text { Liver Stiffness } \\
\text { Measurement } \\
\text { Model [47] }\end{array}$ & $\begin{array}{l}\text { Score Based on } \\
\text { Age, Gender, and } \\
\text { Platelet Count for } \\
\text { HCC in CHB [55] }\end{array}$ \\
\hline Items & $\begin{array}{c}\text { Age } \\
\text { Albumin } \\
\text { Bilirubin } \\
\text { Cirrhosis } \\
\text { HBV DNA level }\end{array}$ & $\begin{array}{c}\text { Age } \\
\text { Gender } \\
\text { BCP mutation } \\
\text { Cirrhosis } \\
\text { HBV DNA level }\end{array}$ & $\begin{array}{c}\text { Age } \\
\text { Gender } \\
\text { ALT level } \\
\text { HBeAg status } \\
\text { HBV DNA level }\end{array}$ & $\begin{array}{c}\text { Age } \\
\text { Gender } \\
\text { ALT level } \\
\text { HBeAg status } \\
\text { Liver stiffness value }\end{array}$ & $\begin{array}{c}\text { Age } \\
\text { Albumin } \\
\text { HBV DNA level } \\
\text { Liver stiffness value }\end{array}$ & $\begin{array}{c}\text { Age } \\
\text { Gender } \\
\text { Platelet level }\end{array}$ \\
\hline $\begin{array}{c}\text { Negative } \\
\text { Predictive Value }\end{array}$ & $97 \%$ at 10 years & $99 \%$ at 10 years & $98 \%$ at 10 years & $96.8 \%$ at 5 years & $99.4 \%$ at 10 years & $100 \%$ at 5 years \\
\hline
\end{tabular}

BCP: basal core promoter; ALT, alanine aminotransferase.

\section{Anti-HBV Therapy as Secondary HCC Prevention}

An initiative to increase HBV awareness and treatment was commenced by the WHO and other health agencies in 2016, with the aim of eliminating viral hepatitis by 2030 [58]. High-impact interventions were planned, followed by studies that modeled the hepatitis epidemiology and covered aspects such as increasing sanitation, newborn mass vaccination against HBV, screening, and linkage to care of the infected populations. In patients with an untreated HBV infection, the incidence of HCC increases with the increase in the serum HBV DNA level. The advised first-line regimen for chronic hepatitis B is INF- $\alpha$ and tenofovir (TDF) and entecavir (ETV), which reduces hepatic inflammation via viral suppression [56]. Randomized controlled trials and meta-analyses have demonstrated that administering IFN for a finite duration reduces the risk of HCC in treated compared to untreated patients [59-62]. In most patients, the continued administration of either NA has caused attenuation, but unfortunately not the eradication, of the HCC risk. The persistence of the HCC risk results from NA failing to eradicate cccDNA and the integrated sequences of the HBV DNA. This leads to the limited rates of serum HBsAg clearance in NA-treated patients, whereas the persistence of residual HCC risk has been recognized even in patients who do not show serum HBsAg following anti-viral therapy, specifically in those patients with HBsAg seroclearance occurring after 50 years of age [56]. As per a joint report of the American and European Societies of the Study of the Liver, the pragmatic goal of NA therapy is to achieve a functional HBV cure, defined as permanent HBsAg clearance with or without HBsAg seroconversion after treatment completion [63]. In real-world practice, however, durable suppression of serum HBV DNA coexisting with detectable HBsAg is the expected outcome of most patients treated with NA [11,55,64].

Several large-scale epidemiological studies identify high levels of HBV DNA in the serum as a critical risk factor for HCC development in chronic HBV cases $[65,66]$. The REVEAL-HBV study, which followed more than $3600 \mathrm{HBsAg}$ carriers for an average of 11 years, revealed an independent dose-dependent relationship between a serum HBV DNA level above $2000 \mathrm{IU} / \mathrm{mL}$ and HCC development [39]. Other HBV-related factors associated with an increased risk for HCC include specific variations in the HBV DNA sequence, the HBV genotype, mutations in the basal core promoter, and levels of quantitative HBsAg [67-69]. Given the close relationship 
between these viral characteristics and the risk for HCC, HBV replication is a logical target for preventing HCC in this setting.

The first evidence for preventing HCC with anti-viral therapy in patients with chronic HBV comes from studies with older NAs, such as lamivudine and adefovir. Liaw et al. reported that lamivudine (with a mean treatment duration of 3 years) significantly reduced the HCC risk compared to a placebo (HCC incidence $3.9 \%$ vs. $7.4 \%$; hazard ratio (HR): $0.49 ; p=0.047$ ] [70]. A meta-analysis, including more than 6800 patients, reported similar 4-year HCC rates in lamivudine-treated and control patients [71]. However, these first-generation NAs are no longer used, mainly due to suboptimal virological responses associated with HBV resistance, which is referred to as a low genetic resistance barrier. Currently, the treatment guidelines for HBV unanimously recommend the use of ETV or TDF $[56,72]$. These agents are well-tolerated and have a much higher genetic resistance barrier. Their long-term use induces sustained virological suppression in the vast majority of patients $(>95 \%)$, along with histological improvements and regression of fibrosis and cirrhosis [73,74]. Furthermore, cohort and population studies carried out all across the world demonstrate that long-term use ( $>5$ years) of either ETV or TDF prevents the development of HCC in the majority of patients [11,75-77]. A cohort study from Hong Kong including 1225 chronic HBV patients who were treated with ETV between 2002 and 2015 compared the HCC incidence among ETV-treated patients to the expected HCC incidence calculated with well-established HCC risk scores for a patient with chronic HBV [76]. The reduction in HCC risk achieved with ETV was significant starting from year six of treatment with a standardized incidence ratio of 0.68 (95\% CI: 0.535-0.866). Notably, the HCC-preventing effect of ETV was seen in both cirrhotic and non-cirrhotic patients [76].

\section{Tenofovir or Entecavir: One Better Than the Other?}

Current international treatment guidelines recommend ETV or TDF as equal first-line treatment options for chronic HBV [56,72]. However, several non-randomized studies suggest a lower HCC incidence with TDF than with ETV, which has fueled a discussion of whether one NA is superior to the other. This discussion was kicked off by the results of a large Korean population study indicating a significantly lower risk for HCC in chronic HBV patients treated with TDF compared to those treated with ETV (HR: 0.68) [78]. However, a second Korean cohort study with a largely overlapping patient cohort failed to confirm this and did not show any difference in HCC risk between ETV and TDF (HR: 1.02) [79]. Subsequently, several other observational studies and meta-analyses did not conclude and support the superiority of a single regimen compared to the other [80-84]. The systematic review and meta-analysis by Tseng et al. may resolve this controversy [85]. This analysis corrected some important limitations of earlier attempts to address this point. Confounding factors that were appropriately resolved included addressing the heterogeneous populations, including only a few comparative studies, the pooling of unadjusted data with adjusted data, the presence of overlapping cohorts, and the analysis of HCC data as a dichotomous outcome instead of through time-to-event data. Tseng et al. included 31 studies representing 119,053 patients. When considering the eight studies with matched populations using propensity score matching, there was no difference in the pooled 5-year cumulative HCC incidence between the two NAs $(p=0.87)$. However, elastographic cirrhosis reversion (liver stiffness $<12 \mathrm{kPa}$ ) after five years of treatment was seen in $71 \%$ of patients with pretreatment liver cirrhosis, and it was more common in TDFthan in ETV-treated cases (74\% vs. $62 \%, p=0.04$ ) [86]. Another meta-analysis analyzing 13 studies with multivariable or propensity-score-matched risk assessments, involving around $4000 \mathrm{HCC}$ cases and 80,000 HBV HCC-free patients, showed no difference in HCC incidence between the TDF and ETV treatment groups (HR 0.86, 95\% CI 0.72-1.04) [87]. This outcome was consistent with the propensity-score-matched meta-analysis (HR 0.83 , 95\% CI interval 0.66-1.03) and the subgroup analysis, revealing the marked resemblance of TDF to ETV for HCC prevention, continued in studies with a longer follow-up of more than four years. However, the finding that the similarity between TDF and ETV for 
HCC prevention was lost among patients with a follow-up time shorter than four years ( $p$ interaction $<0.01$ ) led the authors to speculate that the heterogeneous effects of included reports might emerge from the variation in the follow-up time. As all the above-discussed meta-analyses were draining data from the same pool of studies, it is worth noting that more robust scrutiny through single-data patient meta-analysis or a large-scale randomized comparative trial might help to solve the controversy as to which regimen dominates the chemoprevention of HBV-related HCC.

\section{Can We Prevent More Cases of HCC by Treating HBV Patients Earlier?}

The most recent guidelines for HBV treatment (EASL/AASLD) recommend that anti-HBV treatment in people aged $\geq 30 / 40$ years with a viral load of $>2000 \mathrm{IU} / \mathrm{mL}$ is indicated even in the absence of significant fibrosis or increased alanine aminotransferase (ALT) [56,72].

However, abiding by these recommendations does not completely eradicate the risk of HCC (Figure 2). Long-term follow-up data demonstrate a low but persistent risk for HCC in patients treated with long-term NA therapy (annual risk $0.5-1.4 \%$ in non-cirrhotic patients and $0.7-5.0 \%$ in cirrhotic patients) [10]. In addition, studies indicate that the incidence of HCC only starts to drop after five years of NA therapy $[10,11,88]$. Thus, an extended treatment duration might be necessary to maximize the preventive HCC effect and fuel a discussion of whether starting treatment earlier than currently recommended might improve clinical outcomes and decrease the HCC risk [11]. Retrospective data reported by Kim et al. showed that chronic HBV patients who remained untreated had a 2- to 3-fold increased risk of HCC development, requiring liver transplantation, or dying than patients who initiated NA therapy [89].

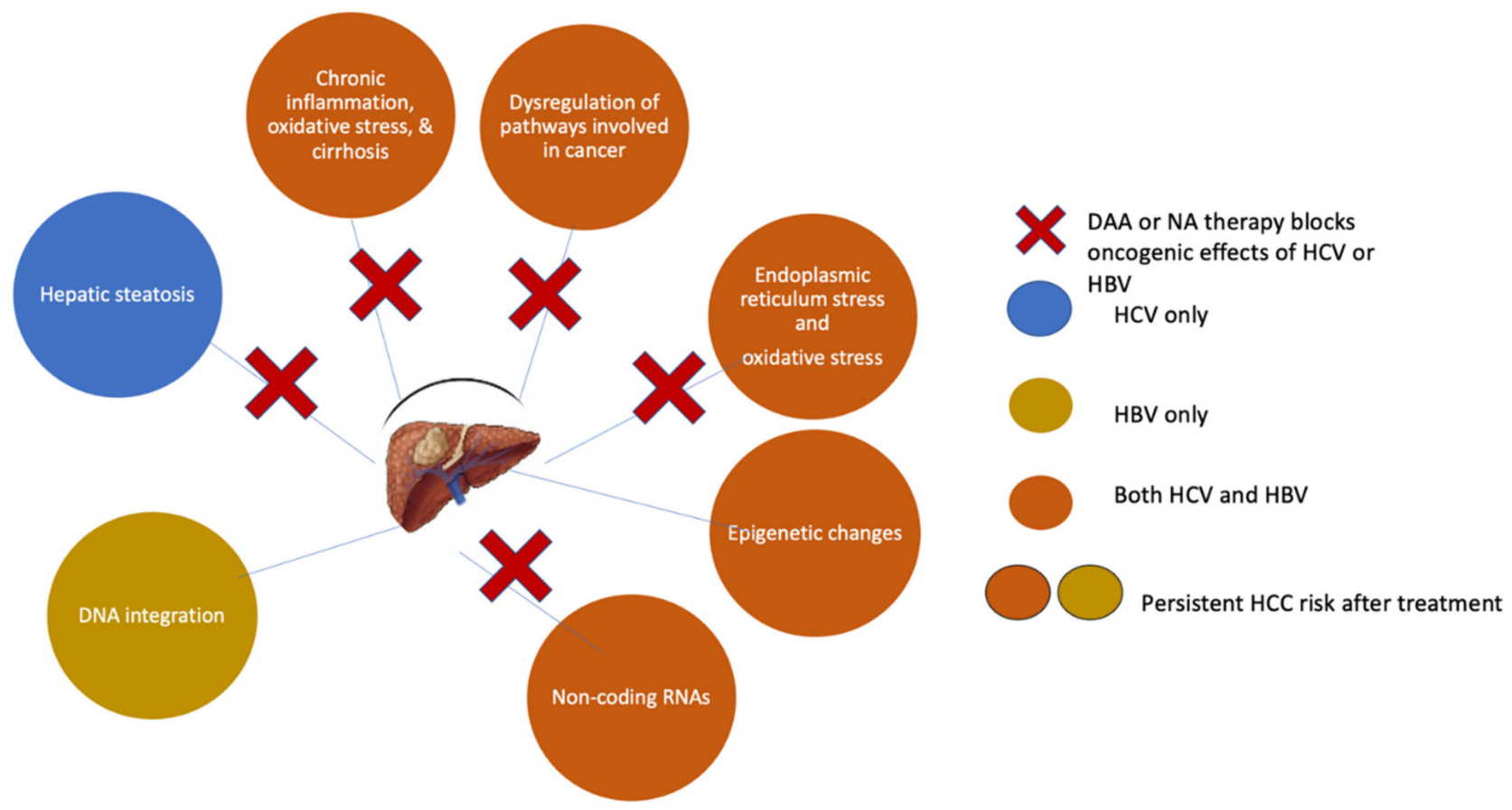

Figure 2. Mechanisms of HCC prevention and risk persistence following DAA or NA therapy.

Initiating anti-viral therapy at an earlier HBV disease stage also has a mechanistic rationale. Studies indicate that genomic integration of HBV DNA, which is a critical oncogenic driver of HBV-related HCC, is frequently detected in young patients with immune-tolerant disease [90]. Additionally, other pro-oncogenic features of HBV, including HBV-specific $\mathrm{T}$ cell responses and hepatic necroinflammatory activity, are often detectable in young immune-tolerant patients [91]. Based on these findings, it is tempting to assume that hepa- 
tocarcinogenesis starts in the immune-tolerant phase of chronic HBV and that oncogenic events accumulate throughout the disease. Thus, the current treatment paradigms would enable decades of unhindered oncogenic events, which a "treatment-for-all" approach would prevent.

Apart from potentially preventing additional cases of HCC, adopting a treatmentfor-all approach in which younger chronic HBV patients are treated with NAs would yield other advantages. It would prevent further patient transmission of HBV and would simplify the management of chronic HBV patients. It would shift the paradigm from a model necessitating multiple tests to assess treatment eligibility (serology, assessment of HBV DNA level, evaluation of liver fibrosis, etc.) to a simple "test-and-treat" approach. Moreover, in the current era of generic NAs, the costs of NA treatment have become lower than the costs of disease monitoring. Cost-efficacy analysis shows that initiating anti-viral therapy in the immune-tolerant phase is cost-effective compared to delaying therapy until patients have progressed to the active hepatitis phase [92]. However, hurdles are still in place preventing the implementation of such a treatment-for-all approach. First, models estimate that nine out of ten chronic HBV patients are not aware that they had the infection, and even when detected, subsequent linkage to care with NA therapy remains suboptimal [93]. A second hurdle relates to the need for lifelong (or prolonged) treatment to prevent a flare-up of the infection, but such a prolonged treatment regimen comes with treatment compliance issues.

\section{Is There a Role for Statins and Aspirin?}

Both aspirin and statins can affect liver cell metabolism and the inflammation associated with hepatocarcinogenesis. A large-cohort study, including over 7700 patients with chronic HBV followed for a median of 7.2 years, showed that statin use (defined as 28 cumulative daily doses) was associated with a $64 \%$ reduced risk for HCC compared to no statin use (adjusted HR (95\% CI): 0.36 (0.19-0.68)). This HCC prevention effect of statins was dose-dependent and observed in all investigated subgroups [94]. The proposed mechanisms of this anticancer effect, which is not limited to HCC but has been reported for other cancers, are believed to be mediated by inhibiting the mevalonate pathway and its downstream products. These products are critical for malignant cell proliferation and the inhibition of hepatic fibrogenesis [95-97]. In addition to this, statins may slow down the synthetic process of cholesterol and the replication of HBV, thus possessing anti-HBV activity [98].

A similar preventive HCC effect for aspirin was described in a cohort study conducted across Taiwan, including over 10,000 patients with chronic HBV. The cumulative incidence of HCC was significantly lower among chronic HBV patients who received daily aspirin for $\geq 90$ days $(n=2123)$ compared to patients who did not $(n=8492)(5.2 \%$ vs. $7.87 \%$; HR (95\%C): $0.71(0.58-0.86) ; p<0.001)$ [99].

Recently, Simon and colleagues analyzed the effect of aspirin on HCC development in 14,205 chronic HBV or HCV patients, with low-dose aspirin intake and found after 7.9 years of follow-up, aspirin significantly lowered the rate of HCC compared to 50,275 chronic HBV or HCV patients with no aspirin intake (4.0\% vs. 8.3\%; HR (95\%C): 0.69 (0.62-0.76); $p<0.001)[100]$.

\section{Novel Treatments}

Hepatic neoplastic transformation in patients who carry HBV involves the clearing process of nuclei (present in infected hepatocytes) from HBV DNA sequences that are integrated into chromosomes and also from free viral cccDNA. Unfortunately, NAs fail to clear those. This may partly explain the residual risk for HCC seen in chronic HBV patients treated with these agents. NA adequately controls HBV replication, but a cure is rare. Therefore, therapy has to be given indefinitely, raising the prospect of selecting drug-resistant virus variants. Pegylated-IFN- $\alpha$-based therapies may in some cases cure the HBV infection but suffer from a moderate response rate and severe side effects. Advances 
in understanding the HBV life cycle are being exploited to develop novel anti-viral agents that suppress HBV replication and inhibit the formation of cccDNA. As the persistence of cccDNA characterizes chronic hepatitis B, this could be a potential target, which is currently not targeted by approved drugs. Agents under investigation include those that block HBV entry into hepatocytes, target cccDNA using CRISPR technology or epigenetic silencing, promote the degradation of viral RNA with RNA interference molecules, or disrupt the production and secretion of viral proteins. Strategies are also used to restore or enhance the anti-HBV immune response.

Moreover, targeting host factors contributing to the life cycle of HBV may present new possibilities for developing innovative therapeutic strategies aiming at an HBV cure. Recent advances in understanding HBV-host interactions highlight how exploiting hosttargeting may lead to a viral cure strategy. Although some of these agents have yielded promising results in early clinical studies, the holy grail of a functional cure for HBV remains elusive $[101,102]$.

\section{Anti-HCV Therapy for the Prevention of HCC}

Like HBV, active HCV infection is central to the hepatocarcinogenic process. Thus, viral elimination is the goal for the secondary prevention of HCC. In this respect, studies from the IFN era convincingly demonstrated that an SVR following IFN-based therapy reduced the risk for HCC to $0.5-1 \%$ per year (vs. $2-8 \%$ per year in untreated chronic $\mathrm{HCV}$ patients with cirrhosis) $[12,103]$. Unfortunately, an SVR to IFN-based therapy was only achieved in half of the patients. Furthermore, IFN toxicity limits its use in patients with cirrhosis.

During the last decade, IFN-free DAA drugs have revolutionized the HCV treatment landscape. An SVR is obtained with these agents in $>95 \%$ of patients, and most show improvements in liver fibrosis and liver function and a reduction in portal hypertension [104]. Moreover, these agents have an excellent safety profile and minimum adverse effects and can be used in patients with decompensated liver disease. Achieving SVR is proven to be beneficial at all stages of fibrosis, including in patients with decompensated cirrhosis; however, the elimination of risk in HCC in patients with decompensated cirrhosis cannot be achieved; therefore, surveillance for HCC is extremely important for patients with advanced fibrosis or cirrhosis after achieving SVR. [105]. Bruno et al. discuss the 'point of no return', since disturbances to the liver architecture in decompensated cirrhosis tend to have a poor prognosis that leads to the development of HCC [106]. Box 1 provides the summary of treatment options for viral hepatitis that are under consideration or development aimed towards HCC prevention.

Box 1. Summary of viral hepatitis treatment options under current consideration or development aimed towards HCC prevention.

- Current international treatment guidelines recommend ETV or TDF as equal first-line treatment options for chronic HBV.

- Pegylated-IFN- $\alpha$-based therapies in selected patients may cure HBV infection; however, it can be associated with significant severe side effects.

- Novel agents under investigation include those that block HBV entry into hepatocytes, target ccCDNA using CRISPR technology or epigenetic silencing, promote the degradation of viral RNA with RNA interference molecules, or disrupt the production and secretion of viral proteins.

- Recent advances in understanding HBV-host interactions highlight how exploiting hosttargeting may lead to a viral cure strategy.

\section{HCC Occurrence after DAA Therapy}

Given the high rate of SVR obtained with DAA, it decreases the risk of HCC and thus reduces the HCV-related morbidity and mortality rates. However, two early reports suggested an unexpectedly high incidence of HCC in HCV patients who achieved SVR after DAA therapy (a 1-year cumulative HCC rate of 3.6\% in one study, a 6-month HCC rate of $4 \%$ in the other) $[107,108]$. Cardoso et al. subsequently reported a 1-year HCC rate 
of $7.4 \%$ and a short median time to HCC development of 7 months [109]. In a study by Ravi et al., an even higher 6-month HCC incidence of 9\% was reported in a cohort of 66 chronic HCV patients with cirrhosis [110]. These controversial results sparked a heated debate on the risk of HCC following an SVR on DAA therapy and fueled hypotheses on the potential involvement of DAAs in hepatocarcinogenesis. However, these initial studies had some crucial drawbacks. They were all characterized by a small sample size, a short follow-up period, and the absence of a control arm. As such, it is no surprise to see that a stream of subsequent studies, both retrospective and prospective, counteracted these findings and firmly established the HCC chemopreventive potential of DAA therapy (Table 2).

A retrospective study by Singer et al. compared the HCC incidence between untreated chronic HCV patients $(n=137,502)$ and patients treated with DAA $(n=30,183)$ or IFN-based therapy $(n=12,948)$. After adjusting for age and cirrhosis status at baseline, DAA-treated patients had a significantly lower risk of HCC than untreated patients (HR (95\% CI): 0.84 (0.73-0.96)) and then patients treated with IFN (HR (95\% CI): 0.69 (059-0.81)) [111]. A similar $70 \%$ HCC risk reduction with DAA therapy vs. no treatment was reported by Janjua et al. [112].

The importance of adjusting for confounding factors is illustrated by a final retrospective study by Nahon et al., which showed a higher 3-year HCC incidence in patients treated with DAAs compared to those obtaining an SVR with IFN (5.9\% vs. 3.1\%; unadjusted HR (95\% CI): $2.03(1.07-3.84) ; p=0.030)$ [113]. However, it is essential to underscore that this study did not adjust for differences in patients and disease characteristics between the DAA and IFN cohorts. This is particularly important because IFN-based therapy was mainly used in younger chronic HCV patients with mild to severe fibrosis. In contrast, the patients who received DAA therapy were predominantly those with cirrhosis and with advanced age. When an analysis does not correct for these differences, a higher HCC incidence in the DAA cohort is not surprising.

Several prospective studies further undercut the initial reports of a higher risk of early HCC with DAA therapy. A French study that included 7344 chronic HCV patients treated with DAAs and 2552 untreated patients confirmed that DAA treatment was associated with a significant decrease in HCC (adjusted HR (95\% CI): 0.66 (0.46-0.91)) [114]. A prospective multicenter cohort study including 1400 Latin American patients with chronic HCV (median follow-up: 16 months) showed that an SVR with DAA regimens was associated with a $73 \%$ relative risk reduction for de novo HCC with a cumulative HCC incidence in cirrhotic patients of 0.02 and 0.04 at 12 and 24 months, respectively [115].

Table 2. Selection of retrospective and prospective studies evaluating the incidence of de novo HCC in DAA-treated HCV patients (adapted from Muzica et al.) [116].

\begin{tabular}{|c|c|c|c|}
\hline Reference & Patient Population & Follow-Up & $\begin{array}{l}\text { De Novo HCC Incidence in } \\
\text { DAA-Treated Patients }\end{array}$ \\
\hline \multicolumn{4}{|c|}{ Retrospective Studies } \\
\hline Conti et al. [108] & $\begin{array}{l}n=285 ; \text { cirrhotic } \\
\text { DAA-treated }\end{array}$ & Mean 5.6 months & $3.26 \%$ \\
\hline Ravi et al. [110] & $n=66 ;$ cirrhotic, DAA-treated & 6 months & 6-month rate: $9.1 \%$ \\
\hline Cardoso et al. [109] & $n=240 ;$ cirrhotic DAA-treated & Median 12 months & 1-year rate: $7.4 \%$ \\
\hline Singer et al. [111] & $\begin{array}{c}\text { Chronic HCV, DAA-treated } \\
(n=30,183), \text { IFN-treated }(n= \\
12,948), \text { or untreated }(n= \\
13,7502)\end{array}$ & Mean 1.05 years & 1.18 per 100 person-years \\
\hline Nahon et al. [113] & $\begin{array}{l}\text { Compensated cirrhotic; } \\
\text { DAA-treated }(n=336), \\
\text { IFN-treated with SVR }(n= \\
\text { 495), or IFN-treated without } \\
\text { SVR }(n=439)\end{array}$ & Median 21.2 months & 2.6 per 100 person-years \\
\hline
\end{tabular}


Table 2. Cont.

\begin{tabular}{|c|c|c|c|}
\hline Reference & Patient Population & Follow-Up & $\begin{array}{l}\text { De Novo HCC Incidence in } \\
\text { DAA-Treated Patients }\end{array}$ \\
\hline Ioannou et al. [117] & $\begin{array}{l}\text { DAA-treated }(n=21948), \\
\text { IFN-treated }(n=35871), \text { DAA } \\
\quad+\text { IFN treated }(n=4535)\end{array}$ & Mean 6.1 years & 1.32 per 100 person-years \\
\hline Kanwal et al. [13] & $n=22,500 ;$ DAA-treated & Mean 1.02 years & 1.18 per 100 person-years \\
\hline Kanwal et al. [118] & $n=18,076 ;$ DAA-treated, SVR & Mean 2.9 years & 3-year rate: $3 \%$ \\
\hline Janjua et al. [112] & $\begin{array}{c}\text { IFN-treated }(n=8871), \\
\text { DAA-treated }(n=3905), \text { SVR }\end{array}$ & Median 1.0 year & 6.9 per 1000 person-years \\
\hline Tani et al. [119] & DAA-treated $(n=1088)$ & Median 13.8 months & 3-year rate: $3.71 \%$ \\
\hline Watanabe et al. [120] & DAA-treated $(n=1438)$ & Median 803 days & $3.82 \%$ \\
\hline \multicolumn{4}{|c|}{ Prospective Studies } \\
\hline Cheung et al. [121] & $\begin{array}{c}\text { DAA-treated }(n=406), \\
\text { untreated } \\
(n=261) ; \text { decompensated } \\
\text { cirrhosis }\end{array}$ & Median 18 months & $4 \%$ \\
\hline Mettke et al. [122] & $\begin{array}{l}\text { DAA-treated }(n=158), \\
\text { untreated } \\
(n=184)\end{array}$ & Median 440 days & 2.9 per 100 person-years \\
\hline Carrat et al. [114] & $\begin{array}{l}\text { DAA-treated }(n=7344) \\
\text { untreated }(n=2552)\end{array}$ & Median 33.4 months & 1.4 per 100 person-years \\
\hline Poordad et al. [123] & DAA-treated $(n=2211)$ & $\begin{array}{l}156 \text { weeks from end of } \\
\text { treatment }\end{array}$ & $1.4 \%$ \\
\hline Piñero et al. [115] & DAA-treated $(n=1.017)$ & Median 16 months & $\begin{array}{l}\text { Cumulative incidence } 0.04 \text { at } \\
24 \text { months }\end{array}$ \\
\hline Sangiovanni et al. [124] & DAA-treated $(n=1285)$ & Mean 17 months & 3.1 per 100 person-years \\
\hline Romano et al. [125] & DAA-treated $(n=3917)$ & Median 523 days & 0.97 per 100 person-years \\
\hline
\end{tabular}

In conclusion, DAA therapy has a preventive effect on the development of HCC in patients with chronic HCV. The initial observation of an increased incidence of HCC in patients who achieved SVR after treatment with DAA therapy could be explained by the theory of early HCC development may have occurred in those with liver nodules undefined by magnetic resonance imaging while commencing DAA treatment. This may be promoted by the imbalance in field immunity caused by the swift eradication of HCV [126].

\section{HCC Recurrence in DAA-Treated Patients}

In the early DAA years, concerns were raised about a higher HCC recurrence risk in HCV patients who had HCC. The studies that formed the basis for the de novo HCC debate also reported an unexpectedly high rate of recurrent HCC, with an HCC recurrence in over a quarter of patients during the first six months following the start of the DAA treatment $[107,108]$. However, as for the de novo HCC risk, subsequent studies have tackled these initial observations and confirmed that DAA therapy reduces the risk of recurrent HCC compared to no treatment. A retrospective study by Lin et al. showed that DAA therapy improved the survival outcomes of HCC patients and did not increase recurrent HCC after curative therapy [127]. This conclusion was further reinforced by a large retrospective study from the United States and Canada, including 793 patients with HCV-related HCC, of whom $304(38.3 \%)$ received DAA therapy and $489(61.7 \%)$ remained untreated. Tumor recurrence was $42.1 \%$ in DAA-treated patients and $58.9 \%$ in untreated patients. As such, these findings underscore that DAA exposure is not associated with an increased risk of HCC recurrence (HR (95\% CI): 0.90 (0.70-1.16)) [128]. Meta- 
analyses support this conclusion. A meta-analysis, including six studies with a follow-up of $1.35-4$ years indicated a $64 \%$ lower risk for HCC recurrence in patients treated with DAA compared to controls (OR (95\% CI): $0.36(0.27-0.47) ; p<0.001)$ [129]. Another meta-analysis, including a total of 2957 patients from 31 studies, found that DAA therapy reduces the risk of HCC recurrence compared to an IFN regimen (RR (95\% CI): $0.64(0.51-0.81)$ ) and no intervention (RR (95\% CI): 0.68 (0.49-0.94)) [130].

\section{Residual HCC Risk Post-SVR and the Need for Surveillance}

DAA therapy for HCV significantly reduces the risk for HCC but does not eliminate it (Figure 2). Although DAA therapy can improve advanced fibrosis and cirrhosis, this process takes time, during which patients still have an increased risk of HCC [131]. In some patients, SVR-induced regression of fibrosis or cirrhosis is counteracted by the acquisition of concomitant liver damage due to alcohol abuse or non-alcoholic steatohepatitis. Additionally, specific HCV-related genetic or epigenetic changes may persist in small pre-cancerous nodules even after achieving an SVR and predispose patients to HCC development. Indeed, Hamdane et al. found that epigenetic changes in histone H3K27ac in the liver tissue of untreated chronic HCV patients were present after HCV clearance by either DAAs or IFN [132]. Similarly, Perez et al. demonstrated persistent epigenetic alterations in liver biopsy samples from patients post-SVR and showed that this epigenetic signature could be reverted in vitro by drugs targeting a chromatin-modifying enzyme [133]. These epigenetic scars could not only act as potential early plasma biomarkers to identify patients at risk for HCC but might also represent therapeutic targets.

The ever-increasing number of patients with HCV clearance with DAAs, combined with the persistent risk of hepatocarcinogenesis even after SVR, emphasizes the need for tools that facilitate the identification of patients with the highest HCC risk. Such tools would enable the development of tailored surveillance programs. Several risk factors for HCC have been identified in patients with chronic HCV who obtained an SVR after anti-viral therapy. In most studies, older age and a fibrosis stage $\geq F 3 / F 4$ were consistent significant risk factors for HCC [134]. In addition, a history of HCC, male sex, diabetes mellitus, heavy alcohol intake, and high gamma-glutamyl transferase and alpha-fetoprotein were found to be associated with a higher HCC risk post-SVR [116,135]. Basal liver stiffness has emerged as a potential predictive factor for HCC in this setting. Rinaldi et al. showed a significantly higher risk for patients with a liver stiffness of $>30 \mathrm{kPa}$ on FibroScan ${ }^{\circledR}(\mathrm{HR}$ (95\% CI): 0.329 (0.131-0.830)). Degasperi et al. identified a baseline liver stiffness above $30 \mathrm{kPa}$ as an independent predictor of de novo HCC (3-year HCC rate of $20 \%$ and $5 \%$ for patients with a liver stiffness $>30 \mathrm{kPa}$ and $\leq 30 \mathrm{kPa}$, respectively) [136].

This long list of risk factors underscores that liver histology is not the only predictor of HCC post-SVR and questions the current surveillance strategies that almost entirely depend on the stage of fibrosis $[137,138]$. It would be more accurate to estimate the HCC risk directly rather than indirectly by extrapolating from the fibrosis stage and use this HCC risk to decide the need for HCC surveillance. A simple tool to estimate the HCC risk in post-SVR HCV patients consists of the fibrosis-4 score (FIB-4), which is calculated using the circulating concentrations of aspartate aminotransferase (AST) and ALT, the age of the patient, and his/her platelet count. In post-SVR patients with HCV, a FIB-4 score of $\geq 3.25$ identifies high-risk patients, and a score of $<3.25$ identifies low-risk patients [139]. Even non-cirrhotic patients with a FIB-4 score $\geq 3.25$ maintain a considerable $1.22 \%$ annual HCC risk, warranting continued HCC surveillance. In contrast, the HCC risk in non-cirrhotic patients with an FIB-4 score below this threshold was very low at only $0.24 \%$, indicating that these patients could potentially forego surveillance. Finally, a change in the FIB- 4 score before and after SVR also seems to hold predictive information. Patients with an FIB-4 score $\geq 3.25$ before and after SVR had an exceptionally high HCC risk of approximately $2 \%$ per year. This was much lower in patients in whom the FIB-4 score dropped below 3.25 post-SVR [139]. Given the association between liver stiffness and HCC risk, FibroScan ${ }^{\circledR}$ - 
related liver stiffness could also be used to assess the HCC risk. Although easy to use, FIB-4 and liver stiffness assessments are not the most accurate tools to assess the HCC risk.

As a more precise alternative, several multivariable regression models have been developed. For example, data from the Veterans Affairs healthcare system was used to establish an HCC risk score that combines SVR, age, sex, body mass index, race or ethnicity, $\mathrm{HCV}$ genotype, platelet count, and the level of AST, ALT, albumin, INR, and hemoglobin to determine a patient's HCC risk [140]. This model predicts that the presence of several HCC risk factors can result in an annual HCC risk of $>1 \%$ in a proportion of non-cirrhotic post-SVR patients, indicating that such patients warrant more active surveillance. Another more straightforward risk score was recently developed (aMAP) that only relies on age, sex, albumin-bilirubin level, and platelet count to calculate the HCC risk. The aMAP score satisfactorily predicted the HCC risk in a cohort of 17,000 patients with viral and non-viral hepatitis from 11 global prospective studies and was excellent in discriminating and calibrating the 5-year HCC risk irrespective of the hepatitis etiology [141].

International society guidelines frequently quote an annual HCC risk threshold of $\geq 1.5 \%$ above which HCC screening is "recommended" and considered cost-effective $[137,138]$. However, the treatment success of anti-HCV therapy has improved since these cost-effectiveness analyses were performed. Newer cost-effectiveness analyses with a specific focus on post-SVR $\mathrm{HCV}$ patients indicates that surveillance could be cost-effective in patients with an annual risk of $>1 \%[142,143]$.

\section{Conclusions}

Chronic infections with HBV or HCV are the dominant causes of HCC globally. The growing body of evidence on the direct and indirect hepatocarcinogenic effects of these viruses underscores the importance of viral eradication as a secondary prevention measure for HCC. Over the last years, a long list of retrospective and prospective studies has convincingly demonstrated the HCC-preventive effects of anti-viral therapy. As far as HBV-related carcinogenesis is concerned, there is overwhelming evidence for the positive impact of the pharmacological suppression of HBV on the risk of HCC. However, even patients who achieve cure following anti-HBV or anti-HCV therapy can still have a persistent residual HCC risk. In this respect, the implementation of dedicated HCC surveillance programs for those patients with the highest HCC risk remains essential. Research continues to be invested in developing novel anti-HBV or anti-HCV therapeutic modalities that could eliminate the HCC risk and develop a predictive model of HCC risk and the best surveillance strategies.

Author Contributions: Conceptualization, S.A.A. and M.C.; methodology, S.A.A. and M.C; investigation, S.A.A. and M.C; data curation, S.A.A. and M.C.; writing-original draft preparation, S.A.A. and M.C.; writing - review and editing, S.A.A. and M.C.; visualization, S.A.A. and M.C. All authors have read and agreed to the published version of the manuscript.

Funding: This research received no external funding.

Institutional Review Board Statement: Not applicable.

Informed Consent Statement: Not applicable.

Data Availability Statement: Not applicable.

Conflicts of Interest: The authors declare no conflict of interest.

\section{References}

1. WHO International Agency for Research on Cancer GLOBOCAN. Available online: https://gco.iarc.fr/today/data/factsheets/ populations /900-world-fact-sheets.pdf (accessed on 3 December 2020).

2. Altekruse, S.F.; McGlynn, K.A.; Reichman, M.E. Hepatocellular Carcinoma Incidence, Mortality, and Survival Trends in the United States from 1975 to 2005. J. Clin. Oncol. 2009, 27, 1485-1491. [CrossRef]

3. Valery, P.C.; Laversanne, M.; Clark, P.; Petrick, J.L.; McGlynn, K.A.; Bray, F. Projections of primary liver cancer to 2030 in 30 countries worldwide. Hepatology 2017, 67, 600-611. [CrossRef] [PubMed] 
4. De Martel, C.; Maucort-Boulch, D.; Plummer, M.; Franceschi, S. World-wide relative contribution of hepatitis B and C viruses in hepatocellular carcinoma. Hepatology 2015, 62, 1190-1200. [CrossRef]

5. Plummer, M.; de Martel, C.; Vignat, J.; Ferlay, J.; Bray, F.; Franceschi, S. Global burden of cancers attributable to infections in 2012: A synthetic analysis. Lancet Glob. Health 2016, 4, e609-e616. [CrossRef]

6. Tang, L.S.Y.; Covert, E.; Wilson, E.; Kottilil, S. Chronic Hepatitis B Infection. JAMA 2018, 319, 1802-1813. [CrossRef]

7. Raffetti, E.; Fattovich, G.; Donato, F. Incidence of hepatocellular carcinoma in untreated subjects with chronic hepatitis B: A systematic review and meta-analysis. Liver Int. 2016, 36, 1239-1251. [CrossRef]

8. WHO. Global Hepatitis Report. 2017. Available online: https://www.who.int/hepatitis/publications/global-hepatitis-report201 7/en/ (accessed on 7 November 2021).

9. Ward, J.W.; Hinman, A.R. What Is Needed to Eliminate Hepatitis B Virus and Hepatitis C Virus as Global Health Threats. Gastroenterology 2019, 156, 297-310. [CrossRef] [PubMed]

10. Papatheodoridis, G.V.; Chan, H.L.-Y.; Hansen, B.E.; Janssen, H.L.; Lampertico, P. Risk of hepatocellular carcinoma in chronic hepatitis B: Assessment and modification with current antiviral therapy. J. Hepatol. 2015, 62, 956-967. [CrossRef] [PubMed]

11. Papatheodoridis, G.V.; Idilman, R.; Dalekos, G.N.; Buti, M.; Chi, H.; Van Boemmel, F.; Calleja-Panero, J.L.; Sypsa, V.; Goulis, J.; Manolakopoulos, S.; et al. The risk of hepatocellular carcinoma decreases after the first 5 years of entecavir or tenofovir in Caucasians with chronic hepatitis B. Hepatology 2017, 66, 1444-1453. [CrossRef]

12. Goodgame, B.; Shaheen, N.J.; Galanko, J.; El-Serag, H.B. The risk of end stage liver disease and hepatocellular carcinoma among persons infected with hepatitis C virus: Publication bias? Am. J. Gastroenterol. 2003, 98, 2535-2542. [CrossRef]

13. Kanwal, F.; Kramer, J.; Asch, S.M.; Chayanupatkul, M.; Cao, Y.; El-Serag, H.B. Risk of Hepatocellular Cancer in HCV Patients Treated with Direct-Acting Antiviral Agents. Gastroenterology 2017, 153, 996-1005. [CrossRef] [PubMed]

14. Mancebo, A.; González-Diéguez, M.L.; Cadahía, V.; Varela, M.; Pérez, R.; Navascués, C.A.; Sotorríos, N.G.; Martínez, M.; Rodrigo, L.; Rodríguez, M. Annual Incidence of Hepatocellular Carcinoma Among Patients with Alcoholic Cirrhosis and Identification of Risk Groups. Clin. Gastroenterol. Hepatol. 2013, 11, 95-101. [CrossRef] [PubMed]

15. Mahale, P.; Torres, H.A.; Kramer, J.R.; Hwang, L.-Y.; Li, R.; Brown, E.L.; Engels, E.A. Hepatitis C virus infection and the risk of cancer among elderly US adults: A registry-based case-control study. Cancer 2017, 123, 1202-1211. [CrossRef] [PubMed]

16. Chang, Y.; Moore, P.S.; Weiss, R.A. Human oncogenic viruses: Nature and discovery. Philos. Trans. R. Soc. B: Biol. Sci. 2017, 372, 20160264. [CrossRef]

17. Lemon, S.M.; McGivern, D.R. Is Hepatitis C Virus Carcinogenic? Gastroenterology 2012, 142, 1274-1278. [CrossRef]

18. Chayanupatkul, M.; Omino, R.; Mittal, S.; Kramer, J.R.; Richardson, P.; Thrift, A.P.; El-Serag, H.B.; Kanwal, F. Hepatocellular carcinoma in the absence of cirrhosis in patients with chronic hepatitis B virus infection. J. Hepatol. 2016, 66, 355-362. [CrossRef]

19. D'Souza, S.; Lau, K.C.; Coffin, C.S.; Patel, T.R. Molecular mechanisms of viral hepatitis induced hepatocellular carcinoma. World J. Gastroenterol. 2020, 26, 5759-5783. [CrossRef]

20. Wölfl, M.; Rutebemberwa, A.; Mosbruger, T.; Mao, Q.; Li, H.-M.; Netski, D.; Ray, S.; Pardoll, D.; Sidney, J.; Sette, A.; et al. Hepatitis C Virus Immune Escape via Exploitation of a Hole in the T Cell Repertoire. J. Immunol. 2008, 181, 6435-6446. [CrossRef]

21. Li, J.; Liao, Z.-X.; Ping, J.; Xu, D.; Wang, H. Molecular mechanism of hepatic stellate cell activation and antifibrotic therapeutic strategies. J. Gastroenterol. 2008, 43, 419-428. [CrossRef] [PubMed]

22. Murakami, S. Hepatitis B virus X protein: A multifunctional viral regulator. J. Gastroenterol. 2001, 36, 651-660. [CrossRef] [PubMed]

23. Cha, M.-Y.; Kim, C.-M.; Park, Y.-M.; Ryu, W.-S. Hepatitis B virus X protein is essential for the activation of Wnt/ $\beta$-catenin signaling in hepatoma cells. Hepatology 2004, 39, 1683-1693. [CrossRef] [PubMed]

24. Dewantoro, O.; Gani, R.A.; Akbar, N. Hepatocarcinogenesis in viral Hepatitis B infection: The role of HBx and p53. Acta Med. Indones. 2006, 38, 154-159.

25. Zhang, B.; Han, S.; Feng, B.; Chu, X.; Chen, L.; Wang, R. Hepatitis B virus X protein-mediated non-coding RNA aberrations in the development of human hepatocellular carcinoma. Exp. Mol. Med. 2017, 49, e293. [CrossRef]

26. Kanda, T.; Goto, T.; Hirotsu, Y.; Moriyama, M.; Omata, M. Molecular Mechanisms Driving Progression of Liver Cirrhosis towards Hepatocellular Carcinoma in Chronic Hepatitis B and C Infections: A Review. Int. J. Mol. Sci. 2019, 20, 1358. [CrossRef] [PubMed]

27. Tawada, A.; Kanda, T.; Imazeki, F.; Yokosuka, O. Prevention of hepatitis B virus-associated liver diseases by antiviral therapy. Hepatol. Int. 2016, 10, 574-593. [CrossRef]

28. Quan, H.; Zhou, F.; Nie, D.; Chen, Q.; Cai, X.; Shan, X.; Zhou, Z.; Chen, K.; Huang, A.; Li, S.; et al. Hepatitis C virus core protein epigenetically silences SFRP1 and enhances HCC aggressiveness by inducing epithelial-mesenchymal transition. Oncogene 2013, 33, 2826-2835. [CrossRef]

29. Tian, Y.; Yang, W.; Song, J.; Wu, Y.; Ni, B. Hepatitis B Virus X Protein-Induced Aberrant Epigenetic Modifications Contributing to Human Hepatocellular Carcinoma Pathogenesis. Mol. Cell. Biol. 2013, 33, 2810-2816. [CrossRef]

30. Braconi, C.; Valeri, N.; Gasparini, P.; Huang, N.; Taccioli, C.; Nuovo, G.; Suzuki, T.; Croce, C.M.; Patel, T. Hepatitis C Virus Proteins Modulate MicroRNA Expression and Chemosensitivity in Malignant Hepatocytes. Clin. Cancer Res. 2010, 16, 957-966. [CrossRef] [PubMed]

31. Zhang, Y.; Wei, W.; Cheng, N.; Wang, K.; Li, B.; Jiang, X.; Sun, S. Hepatitis C virus-induced up-regulation of microRNA-155 promotes hepatocarcinogenesis by activating Wnt signaling. Hepatology 2012, 56, 1631-1640. [CrossRef] 
32. Pekow, J.; Bhan, A.K.; Zheng, H.; Chung, R.T. Hepatic steatosis is associated with increased frequency of hepatocellular carcinoma in patients with hepatitis C-related cirrhosis. Cancer 2007, 109, 2490-2496. [CrossRef]

33. Perlemuter, G.; Sabile, A.; Letteron, P.; Vona, G.; Topilco, A.; Chrétien, Y.; Koike, K.; Pessayre, D.; Chapman, J.; Barba, G.; et al. Hepatitis $C$ virus core protein inhibits microsomal triglyceride transfer protein activity and very low density lipoprotein secretion: A model of viral-related steatosis. FASEB J. 2001, 16, 185-194. [CrossRef]

34. Sung, W.-K.; Zheng, H.; Li, S.; Chen, R.; Liu, X.; Li, Y.; Lee, N.P.; Lee, W.H.; Ariyaratne, P.N.; Tennakoon, C.; et al. Genome-wide survey of recurrent HBV integration in hepatocellular carcinoma. Nat. Genet. 2012, 44, 765-769. [CrossRef] [PubMed]

35. Yan, H.; Yang, Y.; Zhang, L.; Tang, G.; Wang, Y.; Xue, G.; Zhou, W.; Sun, S. Characterization of the genotype and integration patterns of hepatitis B virus in early- and late-onset hepatocellular carcinoma. Hepatology 2015, 61, 1821-1831. [CrossRef]

36. Lau, C.-C.; Sun, T.; Ching, A.K.; He, M.; Li, J.W.; Wong, A.M.; Na Co, N.; Chan, A.W.; Li, P.-S.; Lung, R.W.; et al. Viral-Human Chimeric Transcript Predisposes Risk to Liver Cancer Development and Progression. Cancer Cell 2014, 25, 335-349. [CrossRef] [PubMed]

37. Wang, H.-C.; Wu, H.C.; Chen, C.-F.; Fausto, N.; Lei, H.-Y.; Su, I.-J. Different Types of Ground Glass Hepatocytes in Chronic Hepatitis B Virus Infection Contain Specific Pre-S Mutants that May Induce Endoplasmic Reticulum Stress. Am. J. Pathol. 2003, 163, 2441-2449. [CrossRef]

38. Yang, H.-I.; Lu, S.-N.; Liaw, Y.-F.; You, S.-L.; Sun, C.-A.; Wang, L.-Y.; Hsiao, C.K.; Chen, P.-J.; Chen, D.-S.; Chen, C.-J. Hepatitis B e Antigen and the Risk of Hepatocellular Carcinoma. N. Engl. J. Med. 2002, 347, 168-174. [CrossRef] [PubMed]

39. Chen, C.-J. Risk of Hepatocellular Carcinoma Across a Biological Gradient of Serum Hepatitis B Virus DNA Level. JAMA 2006, 295, 65-73. [CrossRef] [PubMed]

40. Wong, V.W.-S.; Chan, S.L.; Mo, F.; Chan, T.-C.; Loong, H.H.-F.; Wong, G.L.-H.; Lui, Y.Y.-N.; Chan, A.T.-C.; Sung, J.J.-Y.; Yeo, W.; et al. Clinical Scoring System to Predict Hepatocellular Carcinoma in Chronic Hepatitis B Carriers. J. Clin. Oncol. 2010, 28, 1660-1665. [CrossRef]

41. Liu, J.; Tseng, T.-C.; Yang, H.-I.; Lee, M.-H.; Batrla-Utermann, R.; Jen, C.-L.; Lu, S.-N.; Wang, L.-Y.; You, S.-L.; Chen, P.-J.; et al. Predicting Hepatitis B Virus (HBV) Surface Antigen Seroclearance in HBV e Antigen-Negative Patients With Chronic Hepatitis B: External Validation of a Scoring System. J. Infect. Dis. 2014, 211, 1566-1573. [CrossRef] [PubMed]

42. Kim, G.-A.; Lim, Y.-S.; An, J.; Lee, D.; Shim, J.H.; Kim, K.M.; Lee, H.C.; Chung, Y.-H.; Lee, Y.S.; Suh, D.J. HBsAg seroclearance after nucleoside analogue therapy in patients with chronic hepatitis B: Clinical outcomes and durability. Gut 2013, 63, 1325-1332. [CrossRef]

43. Fonseca, M.A.; Ling, J.Z.J.; Al-Siyabi, O.; Co-Tanko, V.; Chan, E.; Lim, S.G.; Jie, J.L.Z. The efficacy of hepatitis B treatments in achieving HBsAg seroclearance: A systematic review and meta-analysis. J. Viral Hepat. 2020, 27, 650-662. [CrossRef]

44. Yang, J.D.; Hainaut, P.; Gores, G.J.; Amadou, A.; Plymoth, A.; Roberts, L.R. A global view of hepatocellular carcinoma: Trends, risk, prevention and management. Nat. Rev. Gastroenterol. Hepatol. 2019, 16, 589-604. [CrossRef] [PubMed]

45. Iida-Ueno, A.; Enomoto, M.; Tamori, A.; Kawada, N. Hepatitis B virus infection and alcohol consumption. World J. Gastroenterol. 2017, 23, 2651-2659. [CrossRef] [PubMed]

46. Chuang, S.-C.; Lee, Y.-C.A.; Hashibe, M.; Dai, M.; Zheng, T.; Boffetta, P. Interaction between Cigarette Smoking and Hepatitis B and C Virus Infection on the Risk of Liver Cancer: A Meta-analysis. Cancer Epidemiol. Biomark. Prev. 2010, 19, 1261-1268. [CrossRef]

47. Wong, G.L.-H.; Chan, H.L.-Y.; Wong, C.K.-Y.; Leung, C.; Chan, C.Y.; Ho, P.P.-L.; Chung, V.C.-Y.; Chan, Z.C.-Y.; Tse, Y.-K.; Chim, A.M.-L.; et al. Liver stiffness-based optimization of hepatocellular carcinoma risk score in patients with chronic hepatitis B. J. Hepatol. 2014, 60, 339-345. [CrossRef] [PubMed]

48. Seto, W.-K.; Hui, R.W.; Mak, L.-Y.; Fung, J.; Cheung, K.-S.; Liu, K.S.; Wong, D.K.-H.; Lai, C.-L.; Yuen, M.-F. Association between Hepatic Steatosis, Measured by Controlled Attenuation Parameter, and Fibrosis Burden in Chronic Hepatitis B. Clin. Gastroenterol. Hepatol. 2018, 16, 575-583. [CrossRef]

49. Tan, Y.; Wei, S.; Zhang, W.; Yang, J.; Yan, L. Type 2 diabetes mellitus increases the risk of hepatocellular carcinoma in subjects with chronic hepatitis B virus infection: A meta-analysis and systematic review. Cancer Manag. Res. 2019, 11, 705-713. [CrossRef] [PubMed]

50. Kim, J.H.; Na Kim, M.; Han, K.-H.; Kim, S.U. Clinical application of transient elastography in patients with chronic viral hepatitis receiving antiviral treatment. Liver Int. 2014, 35, 1103-1115. [CrossRef]

51. Jung, K.S.; Kim, S.U.; Ahn, S.H.; Park, Y.N.; Kim, D.Y.; Park, J.Y.; Chon, C.Y.; Choi, E.; Han, K.-H. Risk assessment of hepatitis B virus-related hepatocellular carcinoma development using liver stiffness measurement (FibroScan). Hepatology 2010, 53, 885-894. [CrossRef]

52. Huang, R.; Jiang, N.; Yang, R.; Geng, X.; Lin, J.; Xu, G.; Liu, D.; Chen, J.; Zhou, G.; Wang, S.; et al. Fibroscan improves the diagnosis sensitivity of liver fibrosis in patients with chronic hepatitis B. Exp. Ther. Med. 2016, 11, 1673-1677. [CrossRef]

53. Yuen, M.-F.; Tanaka, Y.; Fong, D.; Fung, J.; Wong, D.K.-H.; Yuen, J.C.-H.; But, D.Y.-K.; Chan, A.O.-O.; Wong, B.C.-Y.; Mizokami, M.; et al. Independent risk factors and predictive score for the development of hepatocellular carcinoma in chronic hepatitis B. J. Hepatol. 2008, 50, 80-88. [CrossRef]

54. Yang, H.-I.; Yuen, M.-F.; Chan, H.L.-Y.; Han, K.-H.; Chen, P.-J.; Kim, D.-Y.; Ahn, S.H.; Chen, C.-J.; Wong, V.W.-S.; Seto, W.-K. Risk estimation for hepatocellular carcinoma in chronic hepatitis B (REACH-B): Development and validation of a predictive score. Lancet Oncol. 2011, 12, 568-574. [CrossRef] 
55. Papatheodoridis, G.; Dalekos, G.; Sypsa, V.; Yurdaydin, C.; Buti, M.; Goulis, J.; Calleja-Panero, J.L.; Chi, H.; Manolakopoulos, S.; Mangia, G.; et al. PAGE-B predicts the risk of developing hepatocellular carcinoma in Caucasians with chronic hepatitis B on 5-year antiviral therapy. J. Hepatol. 2015, 64, 800-806. [CrossRef] [PubMed]

56. Lampertico, P.; Agarwal, K.; Berg, T.; Buti, M.; Janssen, H.L.; Papatheodoridis, G.; Zoulim, F.; Tacke, F. EASL 2017 Clinical Practice Guidelines on the management of hepatitis B virus infection. J. Hepatol. 2017, 67, 370-398. [CrossRef] [PubMed]

57. Jung, K.S.; Kim, S.U.; Song, K.J.; Park, J.Y.; Kim, D.Y.; Ahn, S.H.; Kim, B.K.; Han, K.-H. Validation of hepatitis B virus-related hepatocellular carcinoma prediction models in the era of antiviral therapy. Hepatology 2015, 62, 1757-1766. [CrossRef] [PubMed]

58. WHO. Global Health Sector Strategy on Viral Hepatitis 2016-2021. Available online: https://apps.who.int/iris/handle/10665/ 246177 (accessed on 7 November 2021).

59. Hsu, C.-S.; Chao, Y.-C.; Lin, H.H.; Chen, D.-S.; Kao, J.-H. Systematic Review: Impact of Interferon-based Therapy on HCV-related Hepatocellular Carcinoma. Sci. Rep. 2015, 5, 9954. [CrossRef]

60. Zhuang, L.; Zeng, X.-T.; Yang, Z.; Meng, Z. Effect and Safety of Interferon for Hepatocellular Carcinoma: A Systematic Review and Meta-Analysis. PLOS ONE 2013, 8, e61361. [CrossRef]

61. Miyake, Y.; Kobashi, H.; Yamamoto, K. Meta-analysis: The effect of interferon on development of hepatocellular carcinoma in patients with chronic hepatitis B virus infection. J. Gastroenterol. 2009, 44, 470-475. [CrossRef]

62. Yang, Y.-F.; Zhao, W.; Zhong, Y.-D.; Xia, H.M.; Shen, L.; Zhang, N. Interferon therapy in chronic hepatitis B reduces progression to cirrhosis and hepatocellular carcinoma: A meta-analysis. J. Viral Hepat. 2009, 16, 265-271. [CrossRef]

63. Cornberg, M.; Lok, A.S.-F.; Terrault, N.A.; Zoulim, F.; Berg, T.; Brunetto, M.R.; Buchholz, S.; Buti, M.; Chan, H.L.; Chang, K.-M.; et al. Guidance for design and endpoints of clinical trials in chronic hepatitis B-Report from the 2019 EASL-AASLD HBV Treatment Endpoints Conference. J. Hepatol. 2019, 72, 539-557. [CrossRef]

64. Chiang, C.-J.; Yang, Y.-W.; Chen, J.-D.; You, S.-L.; Yang, H.-I.; Lee, M.-H.; Lai, M.-S.; Chen, C.-J. Significant reduction in end-stage liver diseases burden through the national viral hepatitis therapy program in Taiwan. Hepatology 2014, 61, 1154-1162. [CrossRef] [PubMed]

65. Kim, H.N.; Newcomb, C.W.; Carbonari, D.M.; Roy, J.A.; Torgersen, J.; Althoff, K.N.; Kitahata, M.M.; Reddy, K.R.; Lim, J.K.; Silverberg, M.J.; et al. Risk of HCC With Hepatitis B Viremia Among HIV/HBV-Coinfected Persons in North America. Hepatology 2021, 74, 1190-1202. [CrossRef] [PubMed]

66. Tseng, T.-C.; Liu, C.-J.; Yang, H.-C.; Su, T.-H.; Wang, C.; Chen, C.; Kuo, S.F.; Liu, C.-H.; Chen, P.-J.; Chen, D.-S.; et al. High Levels of Hepatitis B Surface Antigen Increase Risk of Hepatocellular Carcinoma in Patients with Low HBV Load. Gastroenterology 2012, 142, 1140-1149. [CrossRef]

67. Tseng, T.-C.; Liu, C.-J.; Hsu, C.-Y.; Hong, C.-M.; Su, T.-H.; Yang, W.-T.; Chen, C.-L.; Yang, H.-C.; Huang, Y.-T.; Kuo, S.F.-T.; et al. High Level of Hepatitis B Core-Related Antigen Associated With Increased Risk of Hepatocellular Carcinoma in Patients With Chronic HBV Infection of Intermediate Viral Load. Gastroenterology 2019, 157, 1518-1529. [CrossRef] [PubMed]

68. Liu, S.; Zhang, H.; Gu, C.; Yin, J.; He, Y.; Xie, J.; Cao, G. Associations between Hepatitis B Virus Mutations and the Risk of Hepatocellular Carcinoma: A Meta-Analysis. J. Natl. Cancer Inst. 2009, 101, 1066-1082. [CrossRef] [PubMed]

69. Wong, G.L.-H.; Chan, H.L.-Y.; Yiu, K.K.-L.; Lai, J.W.-Y.; Chan, V.K.-K.; Cheung, K.K.-C.; Wong, E.W.-N.; Wong, V.W.-S. Metaanalysis: The association of hepatitis B virus genotypes and hepatocellular carcinoma. Aliment. Pharmacol. Ther. 2013, 37, 517-526. [CrossRef]

70. Liaw, Y.-F.; Sung, J.J.Y.; Chow, W.C.; Farrell, G.; Lee, C.-Z.; Yuen, H.; Tanwandee, T.; Tao, Q.-M.; Shue, K.; Keene, O.; et al. Lamivudine for Patients with Chronic Hepatitis B and Advanced Liver Disease. N. Engl. J. Med. 2004, 351, 1521-1531. [CrossRef]

71. Singal, A.K.; Salameh, H.; Kuo, Y.-F.; Fontana, R.J. Meta-analysis: The impact of oral anti-viral agents on the incidence of hepatocellular carcinoma in chronic hepatitis B. Aliment. Pharmacol. Ther. 2013, 38, 98-106. [CrossRef]

72. Terrault, N.A.; Lok, A.S.; McMahon, B.J.; Chang, K.-M.; Hwang, J.; Jonas, M.M.; Brown, R.S., Jr.; Bzowej, N.H.; Wong, J.B. Update on prevention, diagnosis, and treatment of chronic hepatitis B: AASLD 2018 hepatitis B guidance. Hepatology 2018, 67, 1560-1599. [CrossRef]

73. Chang, T.-T.; Liaw, Y.-F.; Wu, S.-S.; Schiff, E.; Han, K.-H.; Lai, C.-L.; Safadi, R.; Lee, S.S.; Halota, W.; Goodman, Z.; et al. Long-term entecavir therapy results in the reversal of fibrosis/cirrhosis and continued histological improvement in patients with chronic hepatitis B. Hepatology 2010, 52, 886-893. [CrossRef]

74. Marcellin, P.; Gane, E.; Buti, M.; Afdhal, N.; Sievert, W.; Jacobson, I.M.; Washington, M.K.; Germanidis, G.; Flaherty, J.F.; Schall, R.A.; et al. Regression of cirrhosis during treatment with tenofovir disoproxil fumarate for chronic hepatitis B: A 5-year open-label follow-up study. Lancet 2013, 381, 468-475. [CrossRef]

75. Kim, W.R.; Loomba, R.; Berg, T.; Schall, R.E.A.; Yee, L.J.; Dinh, P.V.; Flaherty, J.F.; Martins, E.B.; Therneau, T.M.; Jacobson, I.; et al. Impact of long-term tenofovir disoproxil fumarate on incidence of hepatocellular carcinoma in patients with chronic hepatitis B. Cancer 2015, 121, 3631-3638. [CrossRef] [PubMed]

76. Ko, K.; To, W.; Mak, L.; Seto, W.; Ning, Q.; Fung, J.; Lai, C.; Yuen, M. A large real-world cohort study examining the effects of long-term entecavir on hepatocellular carcinoma and HBsAg seroclearance. J. Viral Hepat. 2019, 27, 397-406. [CrossRef] [PubMed]

77. Ahn, J.; Lim, J.K.; Lee, H.M.; Lok, A.S.; Nguyen, M.; Pan, C.Q.; Mannalithara, A.; Te, H.; Reddy, R.K.; Trinh, H.; et al. Lower Observed Hepatocellular Carcinoma Incidence in Chronic Hepatitis B Patients Treated With Entecavir: Results of the ENUMERATE Study. Am. J. Gastroenterol. 2016, 111, 1297-1304. [CrossRef] [PubMed] 
78. Choi, J.; Kim, H.J.; Lee, J.; Cho, S.; Ko, M.J.; Lim, Y.-S. Risk of Hepatocellular Carcinoma in Patients Treated with Entecavir vs Tenofovir for Chronic Hepatitis B. JAMA Oncol. 2019, 5, 30-36. [CrossRef] [PubMed]

79. Kim, S.U.; Seo, Y.S.; Lee, H.A.; Na Kim, M.; Lee, Y.R.; Lee, H.W.; Park, J.Y.; Kim, D.Y.; Ahn, S.H.; Han, K.-H.; et al. A multicenter study of entecavir vs. tenofovir on prognosis of treatment-naïve chronic hepatitis B in South Korea. J. Hepatol. 2019, 71, 456-464. [CrossRef]

80. Hsu, Y.-C.; Wong, G.L.-H.; Chen, C.-H.; Peng, C.-Y.; Yeh, M.-L.; Cheung, K.-S.; Toyoda, H.; Huang, C.-F.; Trinh, H.; Xie, Q.; et al Tenofovir Versus Entecavir for Hepatocellular Carcinoma Prevention in an International Consortium of Chronic Hepatitis B. Am. J. Gastroenterol. 2019, 115, 271-280. [CrossRef] [PubMed]

81. Oh, H.; Yoon, E.L.; Jun, D.W.; Ahn, S.B.; Lee, H.-Y.; Jeong, J.Y.; Kim, H.S.; Jeong, S.W.; Kim, S.E.; Shim, J.-J.; et al. No Difference in Incidence of Hepatocellular Carcinoma in Patients with Chronic Hepatitis B Virus Infection Treated With Entecavir vs Tenofovir. Clin. Gastroenterol. Hepatol. 2020, 18, 2793-2802. [CrossRef] [PubMed]

82. Yip, T.C.; Wong, V.W.; Chan, H.L.; Tse, Y.K.; Lui, G.C.; Wong, G.L. Tenofovir Is Associated with Lower Risk of Hepatocellular Carcinoma Than Entecavir in Patients With Chronic HBV Infection in China. Gastroenterology 2020, 158, 215-225. [CrossRef]

83. Lee, S.W.; Kwon, J.H.; Lee, H.L.; Yoo, S.H.; Nam, H.C.; Sung, P.S.; Nam, S.W.; Bae, S.H.; Choi, J.Y.; Yoon, S.K.; et al. Comparison of tenofovir and entecavir on the risk of hepatocellular carcinoma and mortality in treatment-naïve patients with chronic hepatitis B in Korea: A large-scale, propensity score analysis. Gut 2019, 69, 1301-1308. [CrossRef]

84. Dave, S.; Park, S.; Murad, M.H.; Barnard, A.; Prokop, L.; Adams, L.A.; Singh, S.; Loomba, R. Comparative Effectiveness of Entecavir Versus Tenofovir for Preventing Hepatocellular Carcinoma in Patients with Chronic Hepatitis B: A Systematic Review and Meta-Analysis. Hepatology 2020, 73, 68-78. [CrossRef] [PubMed]

85. Tseng, C.-H.; Hsu, Y.-C.; Chen, T.-H.; Ji, F.; Chen, I.-S.; Tsai, Y.-N.; Hai, H.; Thuy, L.T.T.; Hosaka, T.; Sezaki, H.; et al. Hepatocellular carcinoma incidence with tenofovir versus entecavir in chronic hepatitis B: A systematic review and meta-analysis. Lancet Gastroenterol. Hepatol. 2020, 5, 1039-1052. [CrossRef]

86. Papatheodoridi, M.; Hiriart, J.B.; Lupsor-Platon, M.; Bronte, F.; Boursier, J.; Elshaarawy, O.; Marra, F.; Thiele, M.; Markakis, G.; Payance, A.; et al. Refining the Baveno VI elastography criteria for the definition of compensated advanced chronic liver disease. J. Hepatol. 2020, 74, 1109-1116. [CrossRef]

87. Yuan, J.; Peng, Y.; Hao, F.-B.; Wang, Y.-Q.; Wang, C.-R.; Zhong, G.-C. No difference in hepatocellular carcinoma risk in chronic hepatitis B patients treated with tenofovir vs entecavir: Evidence from an updated meta-analysis. Aging 2021, 13, 7147-7165. [CrossRef] [PubMed]

88. Fung, J.; Chok, K.S. The role of oral antiviral therapy in hepatitis B-related hepatocellular carcinoma. Hepatoma Res. 2017, 3, 284. [CrossRef]

89. Kim, G.-A.; Lim, Y.-S.; Han, S.; Choi, J.; Shim, J.H.; Kim, K.M.; Lee, H.C.; Lee, Y.S. High risk of hepatocellular carcinoma and death in patients with immune-tolerant-phase chronic hepatitis B. Gut 2017, 67, 945-952. [CrossRef]

90. Tu, T.; Budzinska, M.A.; Shackel, N.A.; Urban, S. HBV DNA Integration: Molecular Mechanisms and Clinical Implications. Viruses 2017, 9, 75. [CrossRef]

91. Kennedy, P.T.; Sandalova, E.; Jo, J.; Gill, U.; Ushiro-Lumb, I.; Tan, A.T.; Naik, S.; Foster, G.R.; Bertoletti, A. Preserved TCell Function in Children and Young Adults With Immune-Tolerant Chronic Hepatitis B. Gastroenterology 2012, 143, $637-645$. [CrossRef]

92. Kim, H.-L.; Kim, G.-A.; Park, J.-A.; Kang, H.-R.; Lee, E.-K.; Lim, Y.-S. Cost-effectiveness of antiviral treatment in adult patients with immune-tolerant phase chronic hepatitis B. Gut 2020, 70, 2172-2182. [CrossRef]

93. Razavi-Shearer, D.; Gamkrelidze, I.; Nguyen, M.H.; Chen, D.-S.; Van Damme, P.; Abbas, Z.; Abdulla, M.; Rached, A.A.; Adda, D.; Aho, I.; et al. Global prevalence, treatment, and prevention of hepatitis B virus infection in 2016: A modelling study. Lancet Gastroenterol. Hepatol. 2018, 3, 383-403. [CrossRef]

94. Goh, M.J.; Sinn, D.H.; Kim, S.; Woo, S.Y.; Cho, H.; Kang, W.; Gwak, G.; Paik, Y.; Choi, M.S.; Lee, J.H.; et al. Statin Use and the Risk of Hepatocellular Carcinoma in Patients With Chronic Hepatitis B. Hepatology 2019, 71, 2023-2032. [CrossRef] [PubMed]

95. Singh, S.; Singh, P.P.; Singh, A.G.; Murad, M.H.; Sanchez, W. Statins Are Associated with a Reduced Risk of Hepatocellular Cancer: A Systematic Review and Meta-analysis. Gastroenterology 2013, 144, 323-332. [CrossRef] [PubMed]

96. Jiang, P.; Mukthavaram, R.; Chao, Y.; Nomura, N.; Bharati, I.S.; Fogal, V.; Pastorino, S.; Teng, D.; Cong, X.; Pingle, S.C.; et al. In vitro and in vivo anticancer effects of mevalonate pathway modulation on human cancer cells. Br. J. Cancer 2014, 111, 1562-1571. [CrossRef] [PubMed]

97. Eberlein, M.; Heusinger-Ribeiro, J.; Goppelt-Struebe, M. Rho-dependent inhibition of the induction of connective tissue growth factor (CTGF) by HMG CoA reductase inhibitors (statins). Br. J. Pharmacol. 2001, 133, 1172-1180. [CrossRef]

98. Tsan, Y.-T.; Lee, C.-H.; Wang, J.-D.; Chen, P.-C. Statins and the Risk of Hepatocellular Carcinoma in Patients with Hepatitis B Virus Infection. J. Clin. Oncol. 2012, 30, 623-630. [CrossRef]

99. Lee, T.-Y.; Hsu, Y.-C.; Tseng, H.-C.; Yu, S.-H.; Lin, J.-T.; Wu, M.-S.; Wu, C.-Y. Association of Daily Aspirin Therapy With Risk of Hepatocellular Carcinoma in Patients With Chronic Hepatitis B. JAMA Intern. Med. 2019, 179, 633-640. [CrossRef] [PubMed]

100. Simon, T.G.; Duberg, A.-S.; Aleman, S.; Chung, R.T.; Chan, A.T.; Ludvigsson, J.F. Association of Aspirin with Hepatocellular Carcinoma and Liver-Related Mortality. N. Engl. J. Med. 2020, 382, 1018-1028. [CrossRef]

101. Fanning, G.C.; Zoulim, F.; Hou, J.; Bertoletti, A. Therapeutic strategies for hepatitis B virus infection: Towards a cure. Nat. Rev. Drug Discov. 2019, 18, 827-844. [CrossRef] 
102. Asselah, T.; Loureiro, D.; Boyer, N.; Mansouri, A. Targets and future direct-acting antiviral approaches to achieve hepatitis B virus cure. Lancet Gastroenterol. Hepatol. 2019, 4, 883-892. [CrossRef]

103. Brown, J.L. Interferon therapy reduces the risk for hepatocellular carcinoma. Gut 2000, 47, 610-611. [CrossRef]

104. Baumert, T.F.; Berg, T.; Lim, J.K.; Nelson, D.R. Status of Direct-Acting Antiviral Therapy for Hepatitis C Virus Infection and Remaining Challenges. Gastroenterology 2019, 156, 431-445. [CrossRef]

105. Terrault, N.A.; Hassanein, T.I. Management of the patient with SVR. J. Hepatol. 2016, 65, S120-S129. [CrossRef]

106. Bruno, S.; Boccaccio, V.; Russo, M.L.; Maisonneuve, P. Is the benefit of treating patients with cirrhosis proven? Liver Int. 2016, 36, 21-27. [CrossRef]

107. Reig, M.; Mariño, Z.; Perelló, C.; Iñarrairaegui, M.; Ribeiro, A.; Lens, S.; Díaz, A.; Vilana, R.; Darnell, A.; Varela, M.; et al. Unexpected high rate of early tumor recurrence in patients with HCV-related HCC undergoing interferon-free therapy. J. Hepatol. 2016, 65, 719-726. [CrossRef]

108. Conti, F.; Buonfiglioli, F.; Scuteri, A.; Crespi, C.; Bolondi, L.; Caraceni, P.; Foschi, F.G.; Lenzi, M.; Mazzella, G.; Verucchi, G.; et al. Early occurrence and recurrence of hepatocellular carcinoma in HCV-related cirrhosis treated with direct-acting antivirals. $J$. Hepatol. 2016, 65, 727-733. [CrossRef] [PubMed]

109. Cardoso, H.; Vale, A.M.; Rodrigues, S.; Gonçalves, R.; Albuquerque, A.; Pereira, P.; Lopes, S.; Silva, M.; Andrade, P.; Morais, R.; et al. High incidence of hepatocellular carcinoma following successful interferon-free antiviral therapy for hepatitis $C$ associated cirrhosis. J. Hepatol. 2016, 65, 1070-1071. [CrossRef]

110. Ravi, S.; Axley, P.; Jones, D.; Kodali, S.; Simpson, H.; McGuire, B.M.; Singal, A.K. Unusually High Rates of Hepatocellular Carcinoma After Treatment With Direct-Acting Antiviral Therapy for Hepatitis C Related Cirrhosis. Gastroenterology 2017, 152, 911-912. [CrossRef] [PubMed]

111. Singer, A.W.; Reddy, K.R.; Telep, L.E.; Osinusi, A.O.; Brainard, D.M.; Buti, M.; Chokkalingam, A.P. Direct-acting antiviral treatment for hepatitis $\mathrm{C}$ virus infection and risk of incident liver cancer: A retrospective cohort study. Aliment. Pharmacol. Ther. 2018, 47, 1278-1287. [CrossRef] [PubMed]

112. Janjua, N.Z.; Wong, S.; Darvishian, M.; Butt, Z.A.; Yu, A.; Binka, M.; Alvarez, M.; Woods, R.; Yoshida, E.M.; Ramji, A.; et al. The impact of SVR from direct-acting antiviral- and interferon-based treatments for HCV on hepatocellular carcinoma risk. J. Viral Hepat. 2020, 27, 781-793. [CrossRef] [PubMed]

113. Nahon, P.; Layese, R.; Bourcier, V.; Cagnot, C.; Marcellin, P.; Guyader, D.; Pol, S.; Larrey, D.; De Lédinghen, V.; Ouzan, D.; et al. Incidence of Hepatocellular Carcinoma After Direct Antiviral Therapy for HCV in Patients With Cirrhosis Included in Surveillance Programs. Gastroenterology 2018, 155, 1436-1450. [CrossRef]

114. Carrat, F.; Fontaine, H.; Dorival, C.; Simony, M.; Diallo, A.; Hezode, C.; De Ledinghen, V.; Larrey, D.; Haour, G.; Bronowicki, J.-P.; et al. Clinical outcomes in patients with chronic hepatitis $\mathrm{C}$ after direct-acting antiviral treatment: A prospective cohort study. Lancet 2019, 393, 1453-1464. [CrossRef]

115. Piñero, F.; Mendizabal, M.; Ridruejo, E.; Wolff, F.H.; Ameigeiras, B.; Anders, M.; Schinoni, M.I.; Reggiardo, V.; Palazzo, A.; Videla, M.; et al. Treatment with direct-acting antivirals for HCV decreases but does not eliminate the risk of hepatocellular carcinoma. Liver Int. 2019, 39, 1033-1043. [CrossRef]

116. Muzica, C.M.; Stanciu, C.; Huiban, L.; Singeap, A.-M.; Sfarti, C.; Zenovia, S.; Cojocariu, C.; Trifan, A. Hepatocellular carcinoma after direct-acting antiviral hepatitis C virus therapy: A debate near the end. World J. Gastroenterol. 2020, 26, 6770-6781. [CrossRef] [PubMed]

117. Ioannou, G.N.; Green, P.K.; Berry, K. HCV eradication induced by direct-acting antiviral agents reduces the risk of hepatocellular carcinoma. J. Hepatol. 2018, 68, 25-32. [CrossRef]

118. Kanwal, F.; Kramer, J.R.; Asch, S.M.; Cao, Y.; Li, L.; El-Serag, H.B. Long-Term Risk of Hepatocellular Carcinoma in HCV Patients Treated with Direct Acting Antiviral Agents. Hepatology 2019, 71, 44-55. [CrossRef]

119. Tani, J.; Morishita, A.; Sakamoto, T.; Takuma, K.; Nakahara, M.; Fujita, K.; Oura, K.; Tadokoro, T.; Mimura, S.; Nomura, T.; et al. Simple scoring system for prediction of hepatocellular carcinoma occurrence after hepatitis $\mathrm{C}$ virus eradication by direct-acting antiviral treatment: All Kagawa Liver Disease Group Study. Oncol. Lett. 2020, 19, 2205-2212. [CrossRef]

120. Watanabe, T.; Tokumoto, Y.; Joko, K.; Michitaka, K.; Horiike, N.; Tanaka, Y.; Tada, F.; Kisaka, Y.; Nakanishi, S.; Yamauchi, K.; et al. Sex difference in the development of hepatocellular carcinoma after direct-acting antiviral therapy in patients with HCV infection. J. Med Virol. 2020, 92, 3507-3515. [CrossRef]

121. Cheung, M.C.; Walker, A.J.; Hudson, B.E.; Verma, S.; McLauchlan, J.; Mutimer, D.J.; Brown, A.; Gelson, W.T.; MacDonald, D.C.; Agarwal, K.; et al. Outcomes after successful direct-acting antiviral therapy for patients with chronic hepatitis $C$ and decompensated cirrhosis. J. Hepatol. 2016, 65, 741-747. [CrossRef] [PubMed]

122. Mettke, F.; Schlevogt, B.; Deterding, K.; Wranke, A.; Smith, A.; Port, K.; Manns, M.P.; Vogel, A.; Cornberg, M.; Wedemeyer, $\mathrm{H}$. Interferon-free therapy of chronic hepatitis $\mathrm{C}$ with direct-acting antivirals does not change the short-term risk for de novo hepatocellular carcinoma in patients with liver cirrhosis. Aliment. Pharmacol. Ther. 2017, 47, 516-525. [CrossRef]

123. Poordad, F.; Castro, R.E.; Asatryan, A.; Aguilar, H.; Cacoub, P.; Dieterich, D.; Marinho, R.T.; Carvalho, A.; Siddique, A.; $\mathrm{Hu}$, Y.B.; et al. Long-term safety and efficacy results in hepatitis $\mathrm{C}$ virus genotype 1-infected patients receiving ombitasvir/paritaprevir/ritonavir + dasabuvir \pm ribavirin in the TOPAZ-I and TOPAZ-II trials. J. Viral Hepat. 2020, 27, 497-504. [CrossRef] 
124. Sangiovanni, A.; Alimenti, E.; Gattai, R.; Filomia, R.; Parente, E.; Valenti, L.; Marzi, L.; Pellegatta, G.; Borgia, G.; Gambato, M.; et al. Undefined/non-malignant hepatic nodules are associated with early occurrence of HCC in DAA-treated patients with HCV-related cirrhosis. J. Hepatol. 2020, 73, 593-602. [CrossRef] [PubMed]

125. Romano, A.; Angeli, P.; Piovesan, S.; Noventa, F.; Anastassopoulos, G.; Chemello, L.; Cavalletto, L.; Gambato, M.; Russo, F.P.; Burra, P.; et al. Newly diagnosed hepatocellular carcinoma in patients with advanced hepatitis C treated with DAAs: A prospective population study. J. Hepatol. 2018, 69, 345-352. [CrossRef] [PubMed]

126. Colombo, M.; Boccaccio, V. HCV therapy and risk of liver cancer recurrence: Who to treat? Nat. Rev. Gastroenterol. Hepatol. 2018, 15, 392-393. [CrossRef] [PubMed]

127. Lin, W.-C.; Lin, Y.-S.; Chang, C.-W.; Chang, C.-W.; Wang, T.-E.; Wang, H.-Y.; Chen, M.-J. Impact of direct-acting antiviral therapy for hepatitis C-related hepatocellular carcinoma. PLoS ONE 2020, 15, e0233212. [CrossRef] [PubMed]

128. Singal, A.G.; Rich, N.E.; Mehta, N.; Branch, A.; Pillai, A.; Hoteit, M.; Volk, M.; Odewole, M.; Scaglione, S.; Guy, J.; et al. DirectActing Antiviral Therapy Not Associated with Recurrence of Hepatocellular Carcinoma in a Multicenter North American Cohort Study. Gastroenterology 2019, 156, 1683-1692. [CrossRef] [PubMed]

129. Lui, F.H.; Moosvi, Z.; Patel, A.; Hussain, S.; Duong, A.; Duong, J.; Nguyen, D.L. Decreased risk of hepatocellular carcinoma recurrence with directacting antivirals compared with no treatment for hepatitis C: A meta-analysis. Ann. Gastroenterol. 2020. [CrossRef] [PubMed]

130. Frazzoni, L.; Sikandar, U.; Metelli, F.; Sadalla, S.; Mazzella, G.; Bazzoli, F.; Fuccio, L.; Azzaroli, F. Hepatocellular Carcinoma Recurrence after Hepatitis C Virus Therapy with Direct-Acting Antivirals. A Systematic Review and Meta-Analysis. J. Clin. Med. 2021, 10, 1694. [CrossRef]

131. D’Ambrosio, R.; Aghemo, A.; Rumi, M.G.; Degasperi, E.; Sangiovanni, A.; Maggioni, M.; Fraquelli, M.; Perbellini, R.; Rosenberg, W.; Bedossa, P.; et al. Persistence of hepatocellular carcinoma risk in hepatitis $\mathrm{C}$ patients with a response to IFN and cirrhosis regression. Liver Int. 2018, 38, 1459-1467. [CrossRef]

132. Hamdane, N.; Jühling, F.; Crouchet, E.; El Saghire, H.; Thumann, C.; Oudot, M.A.; Bandiera, S.; Saviano, A.; Ponsolles, C.; Suarez, A.A.R.; et al. HCV-Induced Epigenetic Changes Associated With Liver Cancer Risk Persist After Sustained Virologic Response. Gastroenterology 2019, 156, 2313-2329. [CrossRef]

133. Perez, S.; Kaspi, A.; Domovitz, T.; Davidovich, A.; Lavi-Itzkovitz, A.; Meirson, T.; Holmes, J.A.; Dai, C.-Y.; Huang, C.-F.; Chung, R.T.; et al. Hepatitis $C$ virus leaves an epigenetic signature post cure of infection by direct-acting antivirals. PLoS Genet. 2019, 15, e1008181. [CrossRef]

134. Seo, Y.S.; Na Kim, M.; Kim, S.U.; Kim, S.G.; Um, S.H.; Han, K.-H.; Kim, Y.S. Risk Assessment of Hepatocellular Carcinoma Using Transient Elastography Vs. Liver Biopsy in Chronic Hepatitis B Patients Receiving Antiviral Therapy. Medicine 2016, 95 , e2985. [CrossRef] [PubMed]

135. Rinaldi, L.; Perrella, A.; Guarino, M.; De Luca, M.; Piai, G.; Coppola, N.; Pafundi, P.C.; Ciardiello, F.; Fasano, M.; Martinelli, E.; et al. Incidence and risk factors of early HCC occurrence in HCV patients treated with direct acting antivirals: A prospective multicentre study. J. Transl. Med. 2019, 17, 1-10. [CrossRef] [PubMed]

136. Degasperi, E.; D’Ambrosio, R.; Iavarone, M.; Sangiovanni, A.; Aghemo, A.; Soffredini, R.; Borghi, M.; Lunghi, G.; Colombo, M.; Lampertico, P. Factors Associated With Increased Risk of De Novo or Recurrent Hepatocellular Carcinoma in Patients With Cirrhosis Treated with Direct-Acting Antivirals for HCV Infection. Clin. Gastroenterol. Hepatol. 2019, 17, 1183-1191. [CrossRef]

137. Pawlotsky, J.-M.; Negro, F.; Aghemo, A.; Berenguer, M.; Dalgard, O.; Dusheiko, G.; Marra, F.; Puoti, M.; Wedemeyer, H. EASL Recommendations on Treatment of Hepatitis C 2018. J. Hepatol. 2018, 69, 461-511. [CrossRef] [PubMed]

138. Ghany, M.G.; Morgan, T.R.; Panel, A.H.C.G.; Marks, K.M.; Wyles, D.L.; Aronsohn, A.I.; Bhattacharya, D.; Broder, T.; FaladeNwulia, O.O.; Feld, J.J.; et al. Hepatitis C Guidance 2019 Update: American Association for the Study of Liver Diseases-Infectious Diseases Society of America Recommendations for Testing, Managing, and Treating Hepatitis C Virus Infection. Hepatology 2019, 71, 686-721. [CrossRef] [PubMed]

139. Ioannou, G.N.; Beste, L.A.; Green, P.K.; Singal, A.G.; Tapper, E.B.; Waljee, A.K.; Sterling, R.K.; Feld, J.J.; Kaplan, D.E.; Taddei, T.H.; et al. Increased Risk for Hepatocellular Carcinoma Persists Up to 10 Years After HCV Eradication in Patients with Baseline Cirrhosis or High FIB-4 Scores. Gastroenterology 2019, 157, 1264-1278. [CrossRef]

140. Ioannou, G.N.; Green, P.K.; Beste, L.A.; Mun, E.J.; Kerr, K.; Berry, K. Development of models estimating the risk of hepatocellular carcinoma after antiviral treatment for hepatitis C. J. Hepatol. 2018, 69, 1088-1098. [CrossRef]

141. Fan, R.; Papatheodoridis, G.; Sun, J.; Innes, H.; Toyoda, H.; Xie, Q.; Mo, S.; Sypsa, V.; Guha, I.N.; Kumada, T.; et al. aMAP risk score predicts hepatocellular carcinoma development in patients with chronic hepatitis. J. Hepatol. 2020, 73, 1368-1378. [CrossRef]

142. Zangneh, H.F.; Wong, W.W.; Sander, B.; Bell, C.M.; Mumtaz, K.; Kowgier, M.; van der Meer, A.J.; Cleary, S.; Janssen, H.L.; Chan, K.K.; et al. Cost Effectiveness of Hepatocellular Carcinoma Surveillance after a Sustained Virologic Response to Therapy in Patients With Hepatitis C Virus Infection and Advanced Fibrosis. Clin. Gastroenterol. Hepatol. 2019, 17, 1840-1849. [CrossRef]

143. Ioannou, G.N. HCC surveillance after SVR in patients with F3/F4 fibrosis. J. Hepatol. 2020, 74, 458-465. [CrossRef] 